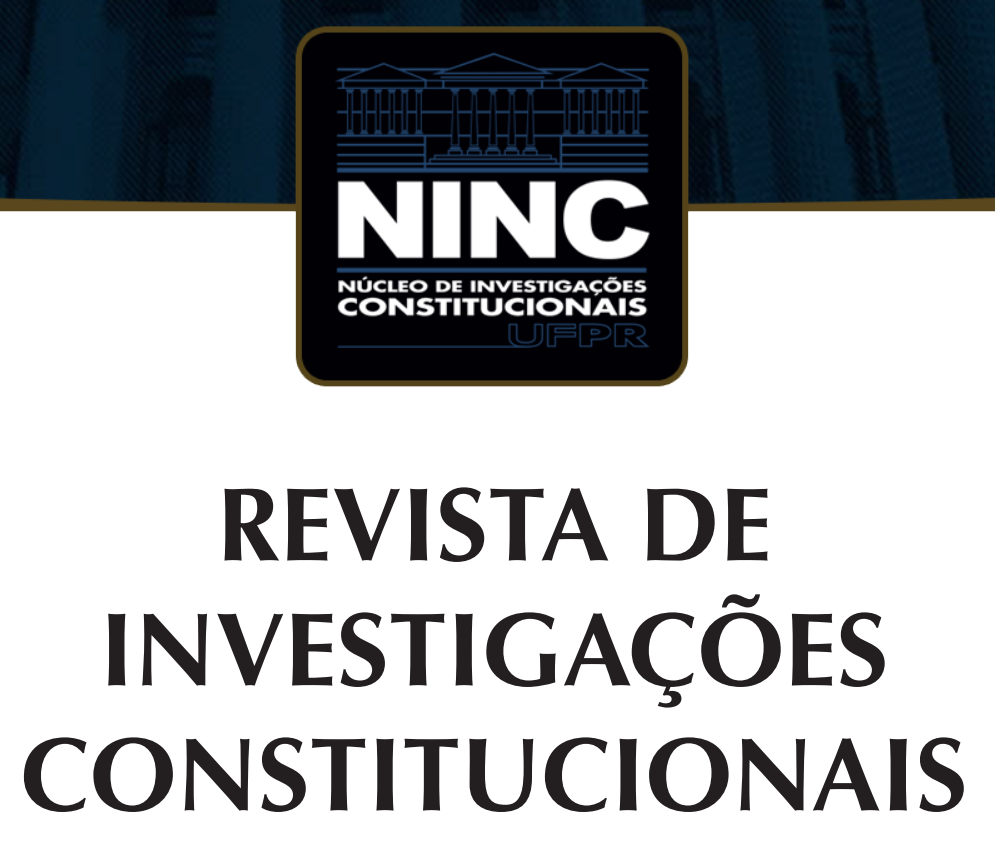

JOURNAL OF CONSTITUTIONAL RESEARCH

vol. 7 | n. 1 | janeiro/abril 2020 | ISSN 2359-5639 | Periodicidade quadrimestral Curitiba | Núcleo de Investigações Constitucionais da UFPR | www.ninc.com.br 


\title{
O Tribunal de Contas da União é um órgão político?
}

\section{Is the Federal Audit Court a political body?}

\author{
FLÁVIO GARCIA CABRAL "," \\ 'Escola de Direito do Ministério Público - EDAMP (Campo Grande, Mato Grosso do Sul, Brasil) \\ flaviocabral_@hotmail.com \\ http://orcid.org/0000-0002-8128-314X \\ Recebido/Received: 21.02.2020 / February $21^{\text {st }}, 2020$ \\ Aprovado/Approved: $17.06 .2020 /$ June $17^{\text {th }}, 2020$
}

\section{Resumo}

O artigo busca investigar se o Tribunal de Contas da União (TCU) pode ser enxergado ou não como um órgão político. Há uma divergência entre a adjetivação que se confere ao TCU, ora sendo denominado de órgão técnico, ora de órgão político. $\mathrm{O}$ trabalho tem por objetivo investigar o caráter político do Tribunal, abordando-se três aspectos diferenciados: a composição dos membros do TCU; a função exercida pela Corte; a influência externa sofrida sobre suas atribuições e a exercida pelo TCU nos processos legislativos. Para a realização do paper, utiliza-se o método de abordagem indutivo, possuindo natureza descritiva e exploratória quanto aos fins e bibliográfica e documental em relação aos meios. Ao final, observa-se que a compreensão do TCU como órgão político depende justamente do critério utilizado. Deste modo, conclui-se que: a) no que tange ao corpo de Ministros do TCU, a Constituição não impede, tampouco fomenta que o Tribunal figure como político; contudo, a prática demonstra que se constitui como político, prevalecendo nomeações

\section{Abstract}

The article seeks to investigate whether or not the Federal Audit Court (TCU) can be seen as a political body. There is a divergence between the adjectivation that is conferred to the Court (TCU), sometimes being called a technical organ, sometimes a political organ. The paper aims to investigate if TCU would have the political character, approaching three differentiated aspects: the composition of TCU members; the function exercised by the Court; the external influence on its attributions and the one exercised by the Federal Audit Court in the legislative processes. For the realization of the paper, the method of inductive approach is used, having descriptive and exploratory nature regarding the purposes and bibliographical and documentary as regards the means. In the end, it is observed that the understanding of TCU as a political organ depends precisely on the criterion used. Thus, it is concluded that: a) Regarding the TCU members, the Constitution does not prevent or encourage the Court to appear as a political body. However, the practice shows that TCU is constituted as political, prevailing

Como citar esse artigo/How to cite this article: CABRAL, Flávio Garcia. O Tribunal de Contas da União é um órgão político? Revista de Investigações Constitucionais, Curitiba, vol. 7, n. 1, p. 237-284, jan./abr. 2020. DOI: 10.5380/rinc.v7i1.71868.

"Professor e coordenador acadêmico da Escola de Direito do Ministério Público - EDAMP (Campo Grande-MS, Brasil). Doutor em Direito Administrativo pela PUC-SP (São Paulo-SP, Brasil). Mestre em Direito Constitucional e Teoria do Estado pela PUC-Rio. Mestre em Direito pela Universitat de Girona/Espanha. Professor de Direito Administrativo e Constitucional em cursos de Graduação e Pós-Graduação. Procurador da Fazenda Nacional (atualmente Procurador-Chefe da Fazenda Nacional em Mato Grosso do Sul).E-mail: flaviocabral_@hotmail.com. 
com esse caráter; b) quando se pauta pela função exercida, o TCU não é político; c) em relação à influência externa sofrida em alguma de suas atribuições, bem como a que exerce no processo legislativo, o TCU figura como órgão político.

Palavras-chave: Tribunal de Contas da União; órgão político; ministros do TCU; função administrativa; discricionariedade. appointments with a political character; $b$ ) when guided by the function performed, TCU is not political; c) in relation to the external influence suffered in some of its attributions, as well as the influence and participation that it exerts in the legislative process, TCU appears like a political organ.

Keywords: Federal Audit Court; political organ; justices of TCU; administrative function; discretion.

\section{SUMÁRIO}

1. Introdução; 2. O dilema do TCU entre órgão político e órgão técnico; 3. Análise quanto aos membros do TCU; 3.1. Campo do dever-ser; 3.2. Campo do ser; 3.3. Conclusões parciais; 4. Análise quanto à atuação/função do TCU; 4.1. Função política ou de governo; 4.2. Compatibilidade com a ordem jurídica brasileira; 4.3. Conclusões parciais; 5. Análise quanto à influência do e sobre o TCU; 5.1. O parecer das contas públicas (artigo 71, i); 5.2. Os trabalhos legislativos; 5.2.1. A constituinte de 87-88; 5.2.2. A alterações da LINDB (Lei 13.655/2018); 5.3. Conclusões parciais; 6. Conclusão; 7. Referências.

\section{INTRODUÇÃO}

A compreensão e leitura acerca do funcionamento das instituições públicas é tarefa da mais alta relevância e importância, uma vez que, de maneira simplista, porém absolutamente acertada, a atuação dos entes públicos é direcionada, direta ou indiretamente, para os cidadãos daquela sociedade. Saber como funcionam as instituições públicas, quais suas funções e atuação, sua natureza, é pressuposto para se realizar justamente um controle, institucional e social, sobre elas e refletir criticamente acerca da necessidade de mudanças na sua forma de se conduzir.

Dentre as várias figuras da Administração Pública que poderiam ser objeto de um estudo que vise a compreender o seu funcionamento, uma que merece destaque é o Tribunal de Contas da União (TCU). Referida instituição superior de controle, que parece vir encontrando a cada dia um maior espaço no cenário institucional e ganhando visibilidade da sociedade, remonta à primeira República no Brasil, mais precisamente um ano antes, em 7 de novembro de 1890, ocasião na qual o então Ministro da Fazenda do Governo Provisório, Rui Barbosa, por meio do Decreto n 966-A, criou o Tribunal de Contas, competindo a este, basicamente, o exame, revisão e julgamento dos atos concernentes à despesa e receita do Brasil-República. A sua criação veio a ser confirmada por meio de inserção expressa no texto da Constituição de 1891.

Todas as demais Constituições brasileiras ao longo da história voltaram a prever a instituição de controle do TCU, alternando basicamente suas atribuições - ora limitando-as, ora ampliando-as. Culmina-se, contudo, com o mais amplo rol de competências constitucionais previstas até hoje, por meio da Constituição de 1988. 
Sem embargo da longa história da Corte de Contas brasileira, pairam dúvidas e questionamentos no que concerne à atuação deste órgão, bem como sobre sua fisionomia e natureza.

Dentre os diversos questionamentos que permeiam a referida instituição, um que representa a problematização a ser investigada reside, então, em saber se o Tribunal de Contas da União poderia ser encarado como um órgão político ou não.

De modo a desenvolver este artigo, a escrita será estruturada da seguinte forma: primeiramente se indicará justamente o impasse entre o TCU figurar como órgão político ou técnico. No capítulo seguinte, abordar-se-á o possível viés político no que tange à composição do TCU, apontando-se as normas constitucionais que versam sobre a seleção dos membros da Corte e como isso tem ocorrido na prática. No terceiro capítulo se discorrerá sobre o aspecto político do TCU em relação à função que desempenha, apurando se o Tribunal exerce ou não a chamada função política ou de governo. Por derradeiro, investigar-se-á se a alcunha de político pode ser atribuída ao TCU levando-se em consideração a influência externa que sofre para o exercício de suas atribuições bem como a sua participação e ingerência no curso dos processos legislativos. Para isso, serão apresentadas algumas considerações sobre como tem ocorrido o exercício da competência do artigo 71, inciso I, da Constituição pelo TCU, bem como dois momentos legislativos nos quais o Tribunal teve participação: a Constituinte de 1987-88 e a edição da Lei n 13.655/2018.

\section{O DILEMA DO TCU ENTRE ÓRGÃO POLÍTICO E ÓRGÃO TÉCNICO}

OTribunal de Contas da União, instituição centenária no Brasil, é órgão que atua, conjuntamente com o Poder Legislativo, no exercício do controle externo da Administração Pública.

Em termos amplos, sua missão se refere ao controle dos gastos públicos, tendo tido, sob a égide da Constituição Federal de 1988, um rol de atribuições muito amplo, cabendo fiscalizar e julgar as contas de todos aqueles que, em certa medida, tiveram contato com patrimônio público.

Veja que para o desempenho de tão importante mister, de nítido caráter republicano, é fundamental a existência de um quadro de pessoal qualificado, aliado a uma estrutura física adequada, e uma série de prerrogativas inerentes aos cargos da Corte de Contas que permitam que as finalidades constitucionais sejam atendidas, sempre em atenção ao regime jurídico de Direito Público.

Para que o TCU alcance sua missão, dentro dos limites constitucionais que lhe são impostos, há a necessidade de uma atuação desempenhada com a seriedade que as atribuições constitucionais demandam. É nessa toada que o TCU é compreendido 
"como órgão eminentemente técnico»" ou ainda como um "órgão técnico especializado, detentor de competências constitucionais específicas de Órgão de fiscalização".2

Não obstante, com certa frequência a Corte de Contas é referida como um órgão político, ${ }^{3}$ questionando-se, por vezes, a lisura do Tribunal devido a seu envolvimento político. ${ }^{4}$ Diz-se ainda que o TCU, ocasionalmente, tem decidido por razões políticas ${ }^{5}$ ou ainda, sem esgotar as adjetivações, é chamado (desta vez sem um caráter desabonador) de uma instituição político-administrativa. ${ }^{6}$

É aqui que reside a dicotomia que permeia o TCU: seria ele um órgão de caráter técnico ou seria cabível lhe imputar a qualificação de político?

Em coluna escrita em 2018, o Procurador de Contas Júlio Marcelo de Oliveira ressalta justamente esse embate, ainda que focando em somente um aspecto do suposto viés político do TCU, assinalando que a Corte, ao tempo em que conta com quadro técnico cada vez mais capacitado, possui em sua composição uma predominância de membros de origem política, o que acaba por evidenciar o quanto a componente política é deletéria em sua atuação. ${ }^{7}$

Evidente que a primeira indagação que se deve fazer é a respeito do que seria um órgão rotulado como técnico ou político.

A problemática parece residir muito mais na nomenclatura do órgão como político. O estudo da Política e suas implicações é temática que perpassa séculos de história e diversos entendimentos. A polissemia do vocábulo "político" faz com que se possa ter várias significações e compreensões na adjetivação.

Deste modo, ao se indagar se o TCU seria um órgão político ou não, precisa-se estabelecer critérios de análise acerca de que sentido o qualificador político está sendo empregado.

\footnotetext{
BRASIL. Supremo Tribunal Federal. Adi no 2.597. Relator: Ministro Eros Roberto Grau. Diário de Justiça. Brasília, 17 ago. 2017.

2 ALMEIDA, Francisco Carlos Ribeiro de. A verdadeira função do Tribunal de Contas da União no processo orçamentário. Revista TCU, Brasília, v.32, n.87, jan./mar. 2001, p.18

3 Vide DIÁRIO DE PERNAMBUCO. Tcu tem que deixar de ser um órgão político, dia líder de governo. Diário de Pernambuco. 06 out. 2015. Disponível: https://www.diariodepernambuco.com.br/app/noticia/politica/2015/10/06/interna_politica,602267/tcu-tem-que-deixar-de-ser-um-orgao-politico-diz-lider-do-governo. shtml. Acesso em: 20 ago. 2019.

4 Vide RIBEIRO, Ana Paula. 'TCU é playground de políticos fracassados', diz Joaquim Barbosa. O Globo. 29 ago. 2015. Disponível em: https://oglobo.globo.com/brasil/tcu-playground-de-politicos-fracassados-diz-joaquim-barbosa-17347428. Acesso em: 30 ago. 2019.

5 SUNDFELD, Carlos Ari; CÂMARA, Jacintho Arruda; MONTEIRO, Vera; ROSILHO, André. O valor das decisões do Tribunal de Contas da União sobre irregularidade em contratos. Revista Direito GV, v.13, n.3, set./dez. 2017, p. 878.

6 BRITTO, Carlos Ayres. O regime constitucional dos Tribunais de Contas. Fórum Administrativo - FA, Belo Horizonte, a. 5, n. 47, jan. 2005.

7 OLIVEIRA, Júlio Marcelo de. O papel dos órgãos de controle externo no combate à corrupção. Consultor Jurídico. 23 out. 2018. Disponível em: https://www.conjur.com.br/2018-out-23/papel-orgaos-controle-externo-combate-corrupcao. Acesso em: 25 jun. 2019.
} 
De início, exclui-se, para os fins deste trabalho, a compreensão do político como sendo algo inerente à atividade de direção suprema e geral do Estado, bem como, em um sentido subjetivo, os órgãos que são responsáveis por essa atividade. ${ }^{8}$ É nesse viés, por exemplo, que Miguel Seabra Fagundes faz uso do termo, ao mencionar que "funções políticas exercem todos os órgãos de cúpula do poder público". ${ }^{9}$ Embora correta essa visão, não é com esta conotação que se faz referência ao TCU como sendo político. Ademais, não decorre maiores problematizações desta forma de encarar um órgão como político.

Dentre as variadas abordagens que se poderia realizar na busca pelo teor do adjetivo "político" atrelado ao Tribunal de Contas, a análise pode ser feita ao menos sob três óticas (distintas, mas que se mostram complementares): político referente a seu corpo (membros); político como referente à função que exerce; político como exercente ou recebedor de influência/pressões políticas na sua atuação.

As consequências de ser considerado órgão político ou não dependerá de cada um dos focos tomados para se aferir o que se entende por «político».

\section{ANÁLISE QUANTO AOS MEMBROS DO TCU}

A composição da Corte de Contas é elemento fundamental para se compreender o funcionamento do órgão de controle e a dinâmica das relações jurídicas estabelecidas. Afinal, é a estrutura conferida ao órgão, que inclui como são escolhidos os seus membros, que contribui na conformação do perfil da instituição.

A esse respeito, pode-se realizar duas análises distintas, embora correlatas, para investigar a estrutura dos membros do TCU: a) descrever o modelo prescritivo (campo do dever-ser) da Constituição vigente no Brasil da seleção dos membros do TCU; b) apurar como tem ocorrido de fato (campo do ser) a escolha dos membros.

Sob esta vertente, denominar de político o órgão de controle diz respeito ao fato de que seus membros são (devem ser) oriundos de cargos políticos ou não.

\subsection{Campo do dever-ser}

Em sua atual composição, o TCU é integrado por nove ministros, ${ }^{10}$ escolhidos de acordo com a distinção feita pelo $\S 2^{\circ}$, ou seja, dois terços (6 ministros) indicados pelo

\footnotetext{
8 ESCOLA, Héctor Jorge. Compendio de Derecho Administrativo. Buenos Aires: Depalma, 1990. V.I, p.16.

9 FAGUNDES, Miguel Seabra. A função política do Supremo Tribunal Federal. Revista de Direito Administrativo - RDA, Rio de Janeiro, v. 134, out./dez.1978, p.2.

10 Odete Medauar enxerga que para um aprimoramento da Corte de Contas brasileira seria benéfico se houvesse um aumento na quantidade de membros do TCU, que deveriam ser auxiliados por um número maior de assistentes (MEDAUAR, Odete. Controle da Administração Pública pelo Tribunal de Contas. Rev. Inf. Legisl., Brasília. a.27, n.108, out./dez. 1990, p.126). Sobre a trajetória da composição do TCU ao longo da história Constitucional brasileira, Bruno Wilhelm Speck informa que o "número inicial de cinco membros com função
} 
Congresso Nacional ${ }^{11-12}$ e um terço (três) indicado pelo Presidente da República, sendo que, neste segundo grupo, um deles indicado livremente pelo chefe do Executivo e os outros dois, de forma alternada, entre os agentes do Ministério Público junto ao TCU e os auditores do Tribunal. Note-se que, de acordo com a redação trazida pelo artigo 35 do Regimento Interno do TCU, na vacância de algum dos ministros, a competência para a escolha será determinada de modo a manter a composição prevista no artigo 73 da Constituição.

A escolha dos Ministros, inclusive para a vaga de livre escolha do Presidente da República, não se encontra totalmente abrangida por uma absoluta discricionariedade, dispondo as normas constitucionais de alguns requisitos mínimos a serem atendidos. Como se observa, o $\$ 1^{\circ}$ do artigo 73 exige requisitos temporais (mais de trinta e cinco e menos de sessenta e cinco anos de idade e mais de dez anos de exercício de função ou de efetiva atividade profissional que exija os conhecimentos mencionados no inciso III, do $\S 1^{\circ}$ do artigo 73 da CF/88) e requisitos substanciais (idoneidade moral e reputação ilibada e notórios conhecimentos jurídicos, contábeis, econômicos e financeiros ou de administração pública) para escolha dos membros do TCU.

Quanto ao primeiro requisito temporal, qual seja, a idade mínima de 35 anos, embora possa se mostrar, em uma primeira análise desatenta, incompatível com as regras constitucionais brasileiras, que vedam a discriminação em razão da idade, percebe-se, como averbado por Jorge Ulisses Jacoby Fernandes, ${ }^{13}$ que há razão de ser para esse limite etário, pois além de manter uma simetria com as exigências constitucionais ao Poder Judiciário, tem-se que a função a ser exercida demanda um maior nível de experiência, vivência e maturidade. A tendência na vigente ordem constitucional tem

\footnotetext{
deliberativa havia sido reduzido para quatro em 1896 . O número de nove membros de 1918 seria restringido para oito em 1931, em função de cortes gerais nos mecanismos de controle. Em 1935, a Lei Orgânica reduziria mais uma vez o número para sete ministros. Somente em 1949, esse número aumentaria outra vez para nove ministros, em função da nova Lei Orgânica do Tribunal, e seria, a partir de então, constante até os nossos dias" (SPECK, Bruno Wilhelm. Inovação e rotina no Tribunal de Contas da União: o papel da instituição superior de controle financeiro no sistema político-administrativo do Brasil. São Paulo: Fundação Konrad Adenauer, 2000, p. 58).

11 Válido destacar que embora a indicação de 6 (seis) Ministros seja feita pelo Congresso Nacional, quem de fato os nomeia é o Presidente da República, conforme se retira do disposto no artigo 84, inciso XV, da Constituição Federal. No entanto, a escolha feita pelo Congresso Nacional não está sujeita ao crivo da apreciação discricionária do Presidente da República, ao contrário do que ocorre na indicação feita pelo próprio Presidente, cujos escolhidos precisam da aprovação do Senado Federal (artigo 52, III, b, da CF/88). Ressalve-se que esta aprovação pelo Senado, como levantado por Márcio Ferreira Kelles, tem se mostrado quase que automática, já que, em consulta realizada junto ao TCU, fora informado que não há até hoje qualquer registro de rejeição pelo Senado do nome indicado para Ministro do Tribunal (KELLES, Márcio Ferreira. Controle da administração pública democrática: Tribunal de Contas no controle da Irf. Belo Horizonte: Fórum, 2007, p.230).

12 Os procedimentos de escolha dos Ministros do TCU pelo Congresso encontram-se atualmente regulamentados pelo Decreto Legislativo $n^{\circ}$ 6, de 22 de abril de 1993.

13 FERNANDES, Jorge Ulisses Jacoby. Tribunal de Contas do Brasil: jurisdição e competência. 2.ed. Belo Horizonte: Fórum, 2008, p.671.
} 
sido, de fato, a nomeação de Ministros com idade bastante superior à mínima exigida, ${ }^{14}$ sendo que a média de idade dos 20 Ministros nomeados durante a atual Constituição de 1988 foi de aproximadamente 55 anos. A idade máxima (65 anos) também se justifica tendo em vista o próprio sistema jurídico brasileiro, uma vez que possui um forte caráter moralizador, evitando que ocorram indicações às vésperas de uma aposentadoria ${ }^{15}$ (que ocorre compulsoriamente aos 75 anos $^{16}$ ), o que desvirtuaria o interesse público almejado. ${ }^{17}$ Neste diapasão, como salientado por Maria Rita Loureiro, Marco Antônio Carvalho Teixeira e Tiago Cacique Moraes, "isso reduziu práticas clientelistas comuns, anteriormente, de nomeação de correligionários políticos com idade próxima dos 70 anos, beneficiando-os, logo a seguir, com aposentadoria integral".18

$\mathrm{O}$ debate mais acirrado surge quando se põem em pauta os requisitos substanciais de escolha dos Ministros. Há quem considere nestes requisitos, em particular se referindo à necessidade de idoneidade moral e reputação ilibada, conceitos de

\footnotetext{
14 O Ministro Bruno Dantas foge da regra ao ser o membro mais jovem a tomar posse na história do TCU, com apenas 36 anos.

15 Na prática a média de idade de saída dos Ministros que chegaram a atuar no curso da Constituição de 1988 alcançou a idade aproximada de 67 anos.

16 O limite de 75 anos para a aposentadoria compulsória dos Ministros do TCU passa a existir por meio da Emenda Constitucional n $88 / 2015$, que trouxe essa previsão em seu artigo $2^{\circ}$. Anteriormente a ela, o limite etário era de 70 anos.
}

17 Acerca do interesse público, cabível rememorar as colocações de Daniel Wunder Hachem, no sentido de que o termo pode ser compreendido em um sentido amplo e em sentido estrito. Na primeira conotação, englobam-se todos os interesses juridicamente protegidos (da coletividade e individuais), na forma de direitos subjetivos ou de interesses legítimos, permanecendo excluídos de suas fronteiras os interesses puros e simples e os interesses ilícitos, que configuram interesses privados. Na segunda visão, interesse público se refere ao interesse da coletividade em si mesma considerada (interesse geral), que pode, no caso concreto, prevalecer sobre interesses específicos (individuais e coletivos) igualmente protegidos pelo ordenamento jurídico, nos termos definidos pelo Direito positivo (HACHEM, Daniel Wunder. A dupla noção jurídica de interesse público em direito administrativo. A\&C - Revista de Direito Administrativo \& Constitucional, Belo Horizonte, ano 11, n. 44, abr./jun. 2011, p.104-105). Sobre o tema, ver também: GABARDO, Emerson. O princípio da supremacia do interesse público sobre o interesse privado como fundamento do Direito Administrativo Social. Revista de Investigações Constitucionais, Curitiba, vol. 4, n. 2, p. 95-130, maio/ago. 2017.

18 LOUREIRO, Maria Rita; TEIXEIRA, Marco Antônio Carvalho; MORAES, Tiago Cacique. Democratização e reforma do Estado: o desenvolvimento institucional dos tribunais de contas no Brasil recente. RAP - Revista de Administração Pública, Rio de Janeiro, 43(4), jul./ago. 2009, p.751. 
"razoável subjetividade", ${ }^{19-20}$ já que seria possível a sua prova negativa, ${ }^{21}$ ou seja, a demonstração da não idoneidade e da não reputação ilibada, sendo eles, inclusive, mas rigorosos que outros conceitos jurídicos positivados, pois, ao prescindirem de registro, tornam inviável a ampla defesa e o contraditório no que concerne à consideração sobre a reprovabilidade de suas condutas e formas de agir. ${ }^{22}$ Entretanto, cabe fazer a ressalva de que exigências qualitativas, como idoneidade moral, conhecimentos profissionais e experiência profissional, constantes da Constituição, sempre deram ampla margem para interpretação, não constituindo um forte critério de pré-seleção profissional e, portanto, não rogaram mudar o perfil de indicações de candidatos do mundo político. ${ }^{23}$

Há que se notar, contudo, que essa forma de escolha de membros do TCU não Ihe é exclusiva na Constituição vigente, podendo-se mencionar como paradigma, ainda que com algumas diferenças, a indicação dos membros do Supremo Tribunal Federal, nos termos do artigo 101 do texto constitucional.

Tendo em vista o amplo espectro interpretativo dos requisitos qualitativos mencionados, a Constituição de 1988 trouxe outros mecanismos a fim de assegurar o profissionalismo de seus membros (pelo menos parcela destes) e a autonomia

19 Embora a assertiva de que é possível delimitar os que não possuam idoneidade e notável saber seja correta, ela não constitui uma verificação que salvaguarde um amplo leque interpretativo que põe em xeque a legitimidade de muitas escolhas. Por se tratar de um conceito indeterminado, sempre haverá uma "zona de penumbra" ou "zona cinzenta", e que, no caso em tela, evidencia-se muito ampla se analisada isoladamente. Neste sentido, Celso Antônio Bandeira de Mello averba que: "Suponha-se outra norma que admita a elevação a certos cargos de pessoas de 'notável saber'. Esta qualificação ensancha o prosperar de análogas hesitações. Se é certo que não se porá em dúvida a presença de tal atributo em alguns casos muito salientes, e se é segura a negação de sua existência em outros tantos assim evidentes, entre as duas situações paradigmáticas vai mediar uma zona de incertezas" (BANDEIRA DE MELLO, Celso Antônio. Curso de direito administrativo. 33.ed. São Paulo: Malheiros, 2016, p.1001).

20 Guilherme Henrique de la Rocque Almeida traz à baila decisão do Supremo Tribunal Federal (STF) (RE n 167.137-TO), onde se decidiu que "os requisitos estatuídos no art.73, §’o, inciso II, da Constituição Federal vinculam o ato administrativo de nomeação aos parâmetros objetivados por nossa Lei Maior". E prossegue afirmando que "Tal vinculação decorre de a norma em questão ter imposto ao administrador o dever de aferir, de forma objetiva, a compatibilidade da situação do nomeado às condições estabelecidas pela Constituição ou por normas infraconstitucionais" (ALMEIDA, Guilherme Henrique de la Rocque. Lei orgânica do Tribunal de Contas da União anotada. Normativos correlatos. Belo Horizonte: Fórum, 2006, p.74).

21 Há na história do TCU um único caso de rejeição de um nome para ocupar a função de Ministro, com base justamente nos fundamentos da idoneidade moral e reputação ilibada. Trata-se da indicação do Senador Luiz Otávio (PMDB-PA), feita pelo Senado em 2003, que, tendo em vista uma série de acusações a que respondia aquele parlamentar (principalmente a denúncia ofertada pelo Ministério Público em 2001, acusando-o da prática de falsidade ideológica e crime contra o sistema financeiro nacional, em razão da fraude perpetrada contra o BNDES no valor de treze milhões de reais), foi impugnada na Justiça, por meio de ação popular, e posteriormente, em 2006, foi rejeitada pela Câmara dos Deputados.

22 FERNANDES, Jorge Ulisses Jacoby. Tribunal de Contas do Brasil: jurisdição e competência. 2.ed. Belo Horizonte: Fórum, 2008, p.671-672.

23 SPECK, Bruno Wilhelm; NAGEL, José. A fiscalização dos recursos públicos pelos tribunais de contas. In: SPECK, Bruno Wilhelm (Org.). Caminhos da transparência: análise dos componentes de um sistema nacional de integridade. Campinas: Editora da Unicamp, 2002, p.196. 
e independência da Corte de Contas. ${ }^{24} \mathrm{O}$ primeiro mecanismo institucional existente refere-se à vinculação da nomeação de pelo menos dois membros do TCU aos profissionais de carreira do próprio Tribunal (dentre auditores e integrantes do Ministério Público de Contas), que ingressaram naquela instituição mediante concurso público de provas e títulos, o que tende, em certa medida, a impedir nomeações de cunho exclusivamente político, e garantir um maior profissionalismo de seus membros.

No que tange ao requisito substancial relativo aos notórios conhecimentos jurídicos, contábeis, econômicos e financeiros ou de administração pública, apreciado em conjunto com o requisito temporal de exigência de 10 anos de exercício em função que demande aqueles requisitos de fundo, alguns pontos merecem consideração. $O$ primeiro é de que a comprovação dos referidos requisitos não demanda a apresentação de títulos específicos ou diplomas referentes a cursos naquelas áreas ${ }^{25}$, ou seja, exige-se conhecimento e não necessariamente formação. O segundo aspecto é de que os conhecimentos mencionados são alternativos e não necessariamente aditivos. Conforme expõe Francisco Eduardo Carrilho Chaves, ${ }^{26}$ deve-se ler o rol de conhecimentos utilizando-se a conjunção "ou" e não "e", porquanto seria exigência demasiadamente excessiva demandar do candidato ao cargo de Ministro notórios conhecimentos jurídicos e contábeis e econômicos e financeiros e de administração pública. Por fim, nesta mesma linha, também não se exige que os dez anos de atividade ocorram em somente uma das áreas ventiladas, podendo haver a mescla entre elas para a complementação do período exigido ${ }^{27}$ (na verdade, torna-se mais interessante que os Ministros tenham uma visão sistêmica das áreas e temas pertinentes aos seus ofícios).

Por último, vê-se que o $\$ 3^{\circ}$ do artigo constitucional ora em estudo versa sobre as prerrogativas, garantias, impedimentos, vencimentos e vantagens dos membros do TCU, equiparando-os aos Ministros do Superior Tribunal de Justiça. ${ }^{28}$ Note-se que a outorga, aos Tribunais de Contas e Controladorias de garantias e impedimentos da Magistratura também se encontra presente, por exemplo, em países como Itália, Espanha, França e Portugal. ${ }^{29}$ Ademais, a Lei Orgânica do TCU (Lei n 8.443/92) disciplina

24 COUTINHO, Doris de Miranda; SANTOS, Aline Sueli de Salles. O papel do Tribunal de Contas frente à accountability. A\&C - Revista de Direito Administrativo \& Constitucional, Belo Horizonte, ano 18, n. 72, p. 209-233, abr./jun. 2018. p. 216.

25 DECOMAIN, Pedro Roberto. Tribunais de Contas no Brasil. São Paulo: Dialética, 2006, p.68-69.

26 CHAVES, Francisco Eduardo Carrilho. Controle externo da gestão pública: a fiscalização pelo legislativo e pelos tribunais de contas. 2.ed. Niterói: Impetus, 2009, p.237.

27 CHAVES, Francisco Eduardo Carrilho. Controle externo da gestão pública: a fiscalização pelo legislativo e pelos tribunais de contas. 2.ed. Niterói: Impetus, 2009, p.237.

28 Já em 1963 o Supremo Tribunal Federal entendia ser válida a equiparação de garantias e vedações entre membros do Poder Judiciário e doTCU, editando a Súmula n42, que prevê: "É legítima a equiparação de juízes do Tribunal de Contas, em direitos e garantias, aos membros do Poder Judiciário".

29 CITADINI, Antônio Roque. O controle externo da Administração Pública. São Paulo: Max Limonad, 1995, p.75. Para maiores considerações sobre a perspectiva comparada das Cortes de Contas, confira-se CARVALHO, 
de forma explícita as garantias e prerrogativas dos Ministros em seus incisos do artigo 73, parágrafo único (vitaliciedade, inamovibilidade, irredutibilidade de vencimentos e aposentadoria com proventos integrais), bem como as vedações no artigo $74 .^{30}$

\subsection{Campo do ser}

A intervenção política na escolha dos membros do TCU é comumente criticada por especialistas, ${ }^{31}$ já que, em tese, afeta consideravelmente a independência da Corte de Contas, ${ }^{32}$ uma vez que quem será fiscalizado escolhe o fiscalizador. Como destacado por Bruno Wilhelm Speck e José Nagel, ${ }^{33}$ a politização na indicação dos membros, nomeados pelos Poderes Legislativo e Executivo, traz "o risco de que essas indicações sejam influenciadas por critérios de conveniência política".

Aqueles mesmos autores ${ }^{34}$ indicam que, quando se exige para a nomeação uma cooperação entre os Poderes, como ocorre na situação brasileira, a politização tende,

Fábio Lins de Lessa; RODRIGUES, Ricardo Schneider. O Tribunal de Contas no Brasil e seus congêneres europeus: um estudo comparativo. A\&C - Revista de Direito Administrativo \& Constitucional, Belo Horizonte, ano 18, n. 71, p. 225-248, jan./mar. 2018 e CABRAL, Flávio Garcia. O Tribunal de Contas da União na Constituição Federal de 1988. São Paulo: Verbatim, 2014, p.75-96.

30 "Art. 74. É vedado ao ministro do Tribunal de Contas da União:

I - exercer, ainda que em disponibilidade, outro cargo ou função, salvo uma de magistério;

II - exercer cargo técnico ou de direção de sociedade civil, associação ou fundação, de qualquer natureza ou finalidade, salvo de associação de classe, sem remuneração;

III - exercer comissão remunerada ou não, inclusive em órgãos de controle da administração direta ou indireta, ou em concessionárias de serviço público;

IV - exercer profissão liberal, emprego particular, comércio, ou participar de sociedade comercial, exceto como acionista ou cotista sem ingerência;

V - celebrar contrato com pessoa jurídica de direito público, empresa pública, sociedade de economia mista, fundação, sociedade instituída e mantida pelo poder público ou empresa concessionária de serviço público, salvo quando o contrato obedecer a normas uniformes para todo e qualquer contratante;

VI - dedicar-se à atividade político-partidária".

31 "E é lógico-dedutivo que, se laços de afinidade ou intimidade existirem, tornará viciado todo o processo de escolha, a toda evidência" (KELLES, Márcio Ferreira. Controle da administração pública democrática: Tribunal de Contas no controle da Irf. Belo Horizonte: Fórum, 2007, p.233).

32 Já na fase da Constituinte, muitos parlamentares levantaram essa questão, querendo afastar a indicação dos membros do TCU pelo Poder Executivo. Tire-se como exemplo o discurso do constituinte Adhemar de Barros Filho, na fase de deliberação da Comissão de Sistematização, onde consignou: "Por mais honoráveis que sejam os membros do Tribunal de Contas, as indicações provenientes da Presidência da República vão revelar algum tipo de ligação, algum tipo de responsabilidade, algum tipo de gratidão, o que empobrece o exercício da função fiscalizadora. Entendo que esta exige a mais total isenção por parte de outro poder para que a função fiscalizadora se exerça com imparcialidade" (ASSEMBLEIA NACIONAL CONSTITUINTE. Diário da Assembleia Nacional Constituinte. Ata da 32a Reunião Extraordinária (29 de outubro de 1987). Brasília: Centro Gráfico do Senado Federal, 1987-1988, p.870).

33 SPECK, Bruno Wilhelm; NAGEL, José. A fiscalização dos recursos públicos pelos tribunais de contas. In: SPECK, Bruno Wilhelm (Org.). Caminhos da transparência: análise dos componentes de um sistema nacional de integridade. Campinas: Editora da Unicamp, 2002, p.237.

34 SPECK, Bruno Wilhelm; NAGEL, José. A fiscalização dos recursos públicos pelos tribunais de contas. In: SPECK, Bruno Wilhelm (Org.). Caminhos da transparência: análise dos componentes de um sistema nacional de integridade. Campinas: Editora da Unicamp, 2002, p.237. 
prima facie, a ser atenuada. No entanto, revêem a premissa transcrita, tendo em vista que nos regimes políticos modernos - novamente como verificado no Brasil - um governo eficiente necessita de bases legislativas fortes para poder governar, razão pela qual, a independência entre os poderes resta diminuta, não garantindo necessariamente uma escolha despolitizada. Assim, nos termos políticos vivenciados pelo Brasil, de coligações partidárias, alternâncias de filiação dos políticos entre os partidos, um atrelamento inconteste entre Executivo e Legislativo, o fato de estar nas mãos do Legislativo a escolha da maioria dos membros do TCU, perde um pouco de sua relevância e eficácia.

Outra questão decorrente da politização da nomeação dos membros do TCU se refere aos financiamentos de campanha eleitoral por empresas privadas. Tendo os Ministros do TCU ocupado cargos políticos anteriormente à sua nomeação ao Tribunal ${ }^{35}$ (como ocorre de fato com a maioria dos membros), não se torna improvável que muitas das empresas ou grupos empresariais que financiaram suas prévias campanhas eleitorais sejam eventualmente objeto de fiscalização pelo TCU, o que põe em xeque a impessoalidade para análise dos referidos processos pelos membros da Corte.

Há, em especial com a Constituição de 1988, uma forte inclinação doutrinária propondo uma melhoria na indicação dos membros do Tribunal, ${ }^{36}$ a fim de prezar pela autonomia e independência de seus membros, sendo a escolha realizada por meio de concurso público ${ }^{37-38}$ uma robusta tendência que vem sendo defendida. Nessa linha ideológica, Odete Medauar ${ }^{39}$ propõe que "melhor seria que a indicação ocorresse

35 Criticando essa nomeação de parlamentares por parlamentares, Charles Pessanha escreveu: "Ao optar por nomear ministros sem a necessária afinidade com as atividades-fim do controle externo, a Câmara dos Deputados e o Senado Federal deixaram de contribuir para o aprimoramento técnico do corpo deliberativo do TCU. Com a indicação preferencial de ex-parlamentares, o Congresso Nacional tornou redundante a dimensão política do controle" (PESSANHA, Charles. Controle externo: a função esquecida pelo Legislativo no Brasil. In: SCHWARTZMAN, Luisa Farah; SCHWARTZMAN, Isabel Farah; SCHWARTZMAN, Felipe Farah; SCHWARTZMAN, Michel Lent (Orgs.). $O$ sociólogo e as políticas públicas: ensaio em homenagem a Simon Schwartzman. Rio de Janeiro: FGV, 2009, p.257).

36 Fabrício Motta sustenta que, embora não seja possível apontar qual a composição mais adequada para as Cortes de Contas, dificilmente haveria um modelo mais inadequado do que o atual modelo brasileiro. Para ele, deveria haver uma reformulação constitucional de modo a predominar os aspectos técnicos sobre o político (MOTTA, Fabrício. Julgamento dos prefeitos municipais: apreciação crítica da mudança imposta pelo Supremo Tribunal Federal. Fórum Municipal \& Gestão das Cidades - FMGC, Belo Horizonte, ano 4, n. 15, jul./set. 2016 , p.43).

37 Conforme se assinalará mais a frente, essa proposta (indicação por concurso público), pelo menos para parcela dos membros do TCU, fez parte dos debates na Constituinte brasileira de 87-88.

38 A utilização de concurso para a escolha dos membros das Cortes de Contas mostra-se como técnica de pouco utilização nos países estrangeiros, podendo-se mencionar como exceção a Itália, onde os juízes de contas das instâncias inferiores são recrutados por concurso, ou ainda a escolha de alguns membros da Cours des Comptes francesa (CITADINI, Antônio Roque. 0 controle externo da Administração Pública. São Paulo: Max Limonad, 1995, p.74-75).

39 MEDAUAR, Odete. Controle da Administração Pública pelo Tribunal de Contas. Rev. Inf. Legisl., Brasília. a.27, n.108, out./dez. 1990, p.126. 
mediante concurso público ${ }^{40}$ de títulos e provas, dentre portadores de diploma de curso superior, nas áreas de direitos, administração, economia ou ciências contábeis, realizado por integrantes de tribunais do Poder Judiciário".

No Tabela 1 colacionada a seguir é possível verificar o perfil dos Ministros do TCU que chegaram a atuar durante a Constituição de 1988, restando evidente que a maioria dos membros possuía atrelamentos políticos antes de ingressar nos quadros do Tribunal.

\begin{tabular}{|c|c|c|c|c|c|c|}
\hline \multicolumn{7}{|c|}{$\begin{array}{c}\text { TABELA } 1 \text { - QUADRO DE INFORMAÇÕES SOBRE OS MINISTROS DO TCU QUE ATUARAM } \\
\text { DURANTE A CONSTITUIÇÃO DE } 1988^{41}\end{array}$} \\
\hline & $\begin{array}{l}\text { NOME DO } \\
\text { MINISTRO }\end{array}$ & $\begin{array}{l}\text { FORMAÇÃO } \\
\text { ACADÊMICA }\end{array}$ & $\begin{array}{c}\text { DATA DE } \\
\text { ADMISSÃO }\end{array}$ & $\begin{array}{l}\text { DATA DA } \\
\text { APOSENTA- } \\
\text { DORIA }\end{array}$ & $\begin{array}{c}\text { GOVER- } \\
\text { NO DA } \\
\text { ADMIS- } \\
\text { SÃO }\end{array}$ & $\begin{array}{l}\text { OCUPAÇÃO } \\
\text { ANTES DA } \\
\text { NOMEAÇÃO }\end{array}$ \\
\hline 1 & $\begin{array}{l}\text { ANA AR- } \\
\text { RAES }\end{array}$ & $\begin{array}{l}\text { Graduação em } \\
\text { Direito }\end{array}$ & $30 / 09 / 2011$ & EM EXERCÍCIO & $\begin{array}{l}\text { Dilma } \\
\text { Rous- } \\
\text { seff }\end{array}$ & $\begin{array}{l}\text { Advogada; } \\
\text { Deputada Fe- } \\
\text { deral. }\end{array}$ \\
\hline 2 & $\begin{array}{l}\text { AROLDO } \\
\text { CEDRAZ }\end{array}$ & $\begin{array}{l}\text { Técnico em } \\
\text { Contabilidade; } \\
\text { Grad u a çã o, } \\
\text { Mestrado e } \\
\text { Doutorado em } \\
\text { Medicina Vete- } \\
\text { rinária. }\end{array}$ & 03/01/2007 & EM EXERCÍCIO & Lula & $\begin{array}{l}\text { Deputado Fe- } \\
\text { deral. }\end{array}$ \\
\hline 3 & $\begin{array}{l}\text { AUGUSTO } \\
\text { NARDES }\end{array}$ & $\begin{array}{l}\text { Graduação em } \\
\text { Administração } \\
\text { de Empresas; } \\
\text { Especialização } \\
\text { em Política } \\
\text { do Desen- } \\
\text { volvimento e } \\
\text { Estatística do } \\
\text { Trabalho; Mes- } \\
\text { trado em Estu- } \\
\text { dos do Desen- } \\
\text { volvimento. }\end{array}$ & $20 / 09 / 2005$ & EM EXERCÍCIO & Lula & $\begin{array}{l}\text { Vereador; De- } \\
\text { putado Esta- } \\
\text { dual; Deputa- } \\
\text { do Federal. }\end{array}$ \\
\hline
\end{tabular}

40 Encontra-se em tramitação a Proposta de Emenda Constitucional n 02/2018 que altera a forma de seleção dos Ministros dos Tribunais de Contas no Brasil, prevendo a indicação de dois membros pelo Presidente da República, dentre os integrantes do corpo de auditores e procuradores do Ministério Público de Contas, e o restante por meio de concurso público de provas e títulos.

41 Tabela elaborada pelo autor. 


\begin{tabular}{|c|c|c|c|c|c|c|}
\hline 4 & $\begin{array}{l}\text { BENJAMIN } \\
\text { ZYMLER }\end{array}$ & $\begin{array}{l}\text { Graduação em } \\
\text { En g e n h a ri a } \\
\text { Elétrica e Direi- } \\
\text { to; Mestrado } \\
\text { em Direito e } \\
\text { Estado. }\end{array}$ & $11 / 09 / 2001$ & EM EXERCÍCIO & FHC & $\begin{array}{l}\text { Engenheiro } \\
\text { Eletricista; Au- } \\
\text { ditor e Minis- } \\
\text { tro Substituto } \\
\text { do TCU. }\end{array}$ \\
\hline 5 & $\begin{array}{l}\text { BRUNO } \\
\text { DANTAS } \\
\text { NASCl- }^{-} \\
\text {MENTO }^{1}\end{array}$ & $\begin{array}{l}\text { G r a d u a çã o } \\
\text { em Direito; } \\
\text { M e s t r a d o, } \\
\text { Doutorado e } \\
\text { Pós-doutorado } \\
\text { em Processo } \\
\text { Civil. }\end{array}$ & $13 / 08 / 2014$ & EM EXERCÍCIO & $\begin{array}{l}\text { Dilma } \\
\text { Rous- } \\
\text { seff }\end{array}$ & $\begin{array}{l}\text { Consultor Le- } \\
\text { gislativo do } \\
\text { Senado; Con- } \\
\text { sultor Geral } \\
\text { do Senado; } \\
\text { Conselheiro } \\
\text { do Conse- } \\
\text { lho Nacional } \\
\text { do Ministé- } \\
\text { rio Público; } \\
\text { Conselheiro } \\
\text { do Conselho } \\
\text { Nacional de } \\
\text { Justiça. }\end{array}$ \\
\hline 6 & $\begin{array}{l}\text { JOSÉ } \\
\text { MUCIO } \\
\text { MONTEI- } \\
\text { RO FILHO }\end{array}$ & $\begin{array}{l}\text { Graduação em } \\
\text { Engenh haria } \\
\text { Civil. }\end{array}$ & $20 / 10 / 2009$ & EM EXERCÍCIO & Lula & $\begin{array}{l}\text { Engenheiro; } \\
\text { Prefeito de } \\
\text { Rio Formoso } \\
\text {-PE; Secretá- } \\
\text { rio de Estado; } \\
\text { Deputado Fe- } \\
\text { deral; Ministro } \\
\text { de Estado. }\end{array}$ \\
\hline 7 & $\begin{array}{l}\text { RAIMUN- } \\
\text { DO CAR- } \\
\text { REIRO }\end{array}$ & $\begin{array}{l}\text { Graduação em } \\
\text { Direito. }\end{array}$ & $14 / 03 / 2007$ & EM EXERCÍCIO & Lula & Vereador. \\
\hline 8 & $\begin{array}{l}\text { VITAL DO } \\
\text { RÊGO } \\
\text { FILHO }\end{array}$ & $\begin{array}{l}\text { Graduação em } \\
\text { Medicina e Di- } \\
\text { reito. }\end{array}$ & $22 / 12 / 2014$ & EM EXERCÍCIO & $\begin{array}{c}\text { Dilma } \\
\text { Rous- } \\
\text { seff }\end{array}$ & $\begin{array}{l}\text { Ve re a d or ; } \\
\text { Deputado Es- } \\
\text { tadual; Depu- } \\
\text { tado Federal; } \\
\text { Senador. }\end{array}$ \\
\hline
\end{tabular}




\begin{tabular}{|c|c|c|c|c|c|c|}
\hline 9 & $\begin{array}{l}\text { WALTON } \\
\text { ALENCAR } \\
\text { RODRI- } \\
\text { GUES }\end{array}$ & $\begin{array}{l}\text { Graduação em } \\
\text { Direito; } \\
\text { Mestrado em } \\
\text { Direito Públi- } \\
\text { co. }\end{array}$ & 13/04/1999 & EM EXERCÍCIO & $\mathrm{FHC}$ & $\begin{array}{l}\text { Analista Le- } \\
\text { gislativo do } \\
\text { Senado Fede- } \\
\text { ral; Advoga- } \\
\text { do; Promotor } \\
\text { de Justiça no } \\
\text { MPDF; Pro- } \\
\text { curador da } \\
\text { Repú blica; } \\
\text { Procurador, } \\
\text { Sub procu- } \\
\text { rador-Geral } \\
\text { e Procura- } \\
\text { dor-Geral do } \\
\text { Ministério Pú- } \\
\text { blico junto ao } \\
\text { TCU. }\end{array}$ \\
\hline 10 & $\begin{array}{l}\text { ALBERTO } \\
\text { HOF- } \\
\text { FMANN }\end{array}$ & $\begin{array}{l}\text { Técnico em } \\
\text { Contabilidade; } \\
\text { Graduação em } \\
\text { Economia. }\end{array}$ & 18/05/1983 & $12 / 03 / 1990$ & $\begin{array}{l}\text { João } \\
\text { Figuei- } \\
\text { redo }\end{array}$ & $\begin{array}{l}\text { Deputado Es- } \\
\text { tadual; Secre- } \\
\text { tário Estadual; } \\
\text { D e p u t a d o } \\
\text { Federal; Sena- } \\
\text { dor. }\end{array}$ \\
\hline 11 & $\begin{array}{l}\text { LUCIANO } \\
\text { BRANDÃO } \\
\text { ALVES DE } \\
\text { SOUZA }\end{array}$ & $\begin{array}{l}\text { Graduação em } \\
\text { Ciências e Le- } \\
\text { tras; Gradua- } \\
\text { ção em Enge- } \\
\text { nharia Civil. }\end{array}$ & 08/12/1977 & 24/06/1994 & $\begin{array}{c}\text { Ernesto } \\
\text { Geisel }\end{array}$ & \begin{tabular}{lr}
\multicolumn{2}{c}{ Diretor-Geral } \\
da & Câmara \\
dos & Deputa- \\
dos. &
\end{tabular} \\
\hline 12 & $\begin{array}{l}\text { ÉLVIA } \\
\text { LORDELLO } \\
\text { CASTELLO } \\
\text { BRANCO }\end{array}$ & $\begin{array}{l}\text { Graduação em } \\
\text { Ciências Jurídi- } \\
\text { cas e Sociais. }\end{array}$ & 10/09/1987 & 06/06/1995 & $\begin{array}{c}\text { José } \\
\text { Sarney }\end{array}$ & $\begin{array}{l}\text { Juíza do Tra- } \\
\text { balho Subs- } \\
\text { tituta do TRT } \\
\text { da } 1^{\circ} \text { Região; } \\
\text { Procuradora- } \\
\text {-Geral junto } \\
\text { ao Tribunal de } \\
\text { Contas do DF. }\end{array}$ \\
\hline
\end{tabular}




\begin{tabular}{|c|c|c|c|c|c|c|}
\hline 13 & $\begin{array}{l}\text { OLAVO } \\
\text { DRUM- } \\
\text { MOND }\end{array}$ & $\begin{array}{l}\text { Graduação em } \\
\text { Direito. }\end{array}$ & 13/06/1990 & $31 / 08 / 1995$ & $\begin{array}{l}\text { Fer- } \\
\text { nando } \\
\text { Collor }\end{array}$ & $\begin{array}{l}\text { Deputado } \\
\text { Estadual e } \\
\text { Suplente de } \\
\text { Deputa do } \\
\text { Federal; Con- } \\
\text { selheiro do } \\
\text { Tribunal de } \\
\text { Contas do Es- } \\
\text { tado de São } \\
\text { Paulo. }\end{array}$ \\
\hline 14 & $\begin{array}{l}\text { PAULO } \\
\text { AFONSO } \\
\text { MARTINS } \\
\text { DE OLIVEI- } \\
\text { RA }\end{array}$ & $\begin{array}{l}\text { Graduação em } \\
\text { Ciências e Le- } \\
\text { tras e em Ciên- } \\
\text { cias Jurídicas e } \\
\text { Sociais. }\end{array}$ & 08/11/1988 & 03/10/1997 & $\begin{array}{l}\text { José } \\
\text { Sarney }\end{array}$ & $\begin{array}{l}\text { Funcionário } \\
\text { da Câmara } \\
\text { dos Deputa- } \\
\text { dos. }\end{array}$ \\
\hline 15 & $\begin{array}{l}\text { FERNAN- } \\
\text { DO GON- } \\
\text { ÇALVES }\end{array}$ & $\begin{array}{l}\text { Graduação em } \\
\text { Direito. }\end{array}$ & 15/06/1982 & 16/04/1998 & $\begin{array}{l}\text { João } \\
\text { Figuei- } \\
\text { redo }\end{array}$ & $\begin{array}{l}\text { Vereador; De- } \\
\text { putado Fede- } \\
\text { ral. }\end{array}$ \\
\hline 16 & $\begin{array}{l}\text { CARLOS } \\
\text { ÁTILA } \\
\text { ÁLVARES } \\
\text { DA SILVA }\end{array}$ & $\begin{array}{l}\text { Graduação em } \\
\text { Ciências Jurídi- } \\
\text { cas e Sociais. }\end{array}$ & $12 / 03 / 1985$ & 18/12/1998 & $\begin{array}{l}\text { José } \\
\text { Sarney }\end{array}$ & $\begin{array}{l}\text { Diplo mata } \\
\text { de Carreira; } \\
\text { Secretário de } \\
\text { Imprensa e } \\
\text { Divulgação da } \\
\text { Presidência } \\
\text { da Republica. }\end{array}$ \\
\hline 17 & $\begin{array}{l}\text { HOMERO } \\
\text { SANTOS }\end{array}$ & $\begin{array}{l}\text { Graduação em } \\
\text { Ciências Jurídi- } \\
\text { cas e Sociais. }\end{array}$ & $31 / 10 / 1988$ & 17/06/1999 & $\begin{array}{c}\text { José } \\
\text { Sarney }\end{array}$ & $\begin{array}{l}\text { Vereador; De- } \\
\text { putado Esta- } \\
\text { dual; Deputa- } \\
\text { do Federal. }\end{array}$ \\
\hline 18 & $\begin{array}{l}\text { ADHEMAR } \\
\text { PALADINI } \\
\text { GHISI }\end{array}$ & $\begin{array}{l}\text { Graduação em } \\
\text { Ciências Jurídi- } \\
\text { cas e Sociais. }\end{array}$ & 06/03/1985 & $16 / 01 / 2001$ & $\begin{array}{c}\text { José } \\
\text { Sarney }\end{array}$ & $\begin{array}{l}\text { Deputado Es- } \\
\text { tadual; Depu- } \\
\text { tado Federal. }\end{array}$ \\
\hline
\end{tabular}




\begin{tabular}{|c|c|c|c|c|c|c|}
\hline 19 & $\begin{array}{l}\text { BENTO } \\
\text { JOSÉ } \\
\text { BUGARIN }\end{array}$ & $\begin{array}{l}\text { G r a d u a çã o } \\
\text { em Direito e } \\
\text { Filosofia; Es- } \\
\text { pecialização } \\
\text { em Adminis- } \\
\text { tração Pública; } \\
\text { Doutorado em } \\
\text { Finanças Públi- } \\
\text { cas (Tributos). }\end{array}$ & 09/11/1995 & $30 / 04 / 2001$ & $\mathrm{FHC}$ & $\begin{array}{l}\text { Conselheiro } \\
\text { Substituto do } \\
\text { Tribunal de } \\
\text { Contas do DF; } \\
\text { Auditor e Mi- } \\
\text { nistro Substi- } \\
\text { tuto do TCU. }\end{array}$ \\
\hline 20 & $\begin{array}{l}\text { IRAM DE } \\
\text { ALMEIDA } \\
\text { SARAIVA }\end{array}$ & $\begin{array}{l}\text { Graduação em } \\
\text { História e Di- } \\
\text { reito. }\end{array}$ & 17/08/1994 & $25 / 08 / 2003$ & $\begin{array}{l}\text { Itamar } \\
\text { Franco }\end{array}$ & $\begin{array}{l}\text { Ve re a d or ; } \\
\text { Deputado Es- } \\
\text { tadual; Depu- } \\
\text { tado Federal; } \\
\text { Senador. }\end{array}$ \\
\hline 21 & $\begin{array}{l}\text { HUMBER- } \\
\text { TO GUI- } \\
\text { MARÃES } \\
\text { SOUTO }\end{array}$ & $\begin{array}{l}\text { Contabilista; } \\
\text { Graduação em } \\
\text { Direito. }\end{array}$ & 24/08/1995 & $02 / 06 / 2004$ & $\mathrm{FHC}$ & $\begin{array}{l}\text { Vereador; De- } \\
\text { putado Esta- } \\
\text { dual; Deputa- } \\
\text { do Federal. }\end{array}$ \\
\hline 22 & $\begin{array}{l}\text { ADYLSON } \\
\text { MOTTA }\end{array}$ & $\begin{array}{l}\text { Graduação em } \\
\text { Odontologia e } \\
\text { Direito. }\end{array}$ & 20/01/1999 & $23 / 08 / 2006$ & $\mathrm{FHC}$ & $\begin{array}{l}\text { Deputado Es- } \\
\text { tadual; Chefe } \\
\text { da Casa Civil } \\
\text { do Governo } \\
\text { do Estado do } \\
\text { Rio Grande do } \\
\text { Sul; Deputado } \\
\text { Federal. }\end{array}$ \\
\hline 23 & $\begin{array}{l}\text { GUILHER- } \\
\text { ME PAL- } \\
\text { MEIRA }\end{array}$ & $\begin{array}{l}\text { Graduação em } \\
\text { Ciências Jurídi- } \\
\text { cas e Sociais. }\end{array}$ & 04/08/1999 & $13 / 11 / 2008$ & $\mathrm{FHC}$ & $\begin{array}{l}\text { D e p u t a d o } \\
\text { Estadual; Go- } \\
\text { vernador do } \\
\text { Estado de Ala- } \\
\text { goas; Sena- } \\
\text { dor; Prefeito } \\
\text { Municipal de } \\
\text { Maceió-AL. }\end{array}$ \\
\hline 24 & $\begin{array}{l}\text { MARCOS } \\
\text { VINICIOS } \\
\text { RODRI- } \\
\text { GUES } \\
\text { VILAÇA }\end{array}$ & $\begin{array}{l}\text { Graduação em } \\
\text { Ciências Jurí- } \\
\text { dicas e Sociais; } \\
\text { Mestrado em } \\
\text { Direito. }\end{array}$ & 19/04/1988 & $26 / 06 / 2009$ & $\begin{array}{l}\text { José } \\
\text { Sarney }\end{array}$ & $\begin{array}{l}\text { Diretor da Cai- } \\
\text { xa Econômica } \\
\text { Federal; Se- } \\
\text { cretário de Es- } \\
\text { tado; Suplen- } \\
\text { te de Senador. }\end{array}$ \\
\hline
\end{tabular}




\begin{tabular}{|c|l|l|l|l|l|l|}
\hline 25 & $\begin{array}{l}\text { UBIRATAN } \\
\text { DINIZ } \\
\text { AGUIAR }\end{array}$ & $\begin{array}{l}\text { Graduação em } \\
\text { Ciências Jurídi- } \\
\text { cas e Sociais. }\end{array}$ & $02 / 05 / 2001$ & 09/09/2011 & FHC & $\begin{array}{l}\text { Vereador; De- } \\
\text { putado Esta- } \\
\text { dual; Deputa- } \\
\text { do Federal. }\end{array}$ \\
\hline 26 & $\begin{array}{l}\text { VALMIR } \\
\text { CAMPELO }\end{array}$ & $\begin{array}{l}\text { Graduação em } \\
\text { Comunicação } \\
\text { Social. }\end{array}$ & $13 / 11 / 1997$ & $07 / 04 / 2014$ & FHC & $\begin{array}{l}\text { Federal; Sena- } \\
\text { dor. }\end{array}$ \\
\hline JOSÉ & $\begin{array}{l}\text { Gra d u ç ã o } \\
\text { JORGE } \\
\text { ria Engenha- } \\
\text { e Mecânica } \\
\text { Especialização } \\
\text { em Estatística; } \\
\text { Mestrado em } \\
\text { Ciências. }\end{array}$ & $03 / 02 / 2009$ & $18 / 11 / 2014$ & Lula & $\begin{array}{l}\text { Secretário de } \\
\text { Estado; Minis- } \\
\text { tro de Estado; } \\
\text { De p u t a d o } \\
\text { Federal; Sena- } \\
\text { dor. }\end{array}$ \\
\hline
\end{tabular}

Apesar de o texto constitucional não fazer nenhuma exigência quanto à origem dos seus Ministros, a prática demonstra que o Tribunal costuma abrigar os pares dos membros do Congresso, bem como ex-ocupantes de diversos cargos de natureza política, como parlamentares ou Secretários e Ministros de Estado.

Do corpo de Ministros atualmente em exercício, há cinco ex-deputados federais, um ex-vereador, dois Ministros oriundos das carreiras atreladas ao TCU (Procurador de Contas e Auditor), por exigência constitucional, e um ex-servidor público do Poder Legislativo.

Embora não seja o objeto da pesquisa, interessante notar que este perfil de nomeações se reproduz em todos os Tribunais de Contas do Estado. ${ }^{42}$ Conforme pesquisa

42 A respeito das indicações políticas em todos os Tribunais de Contas, Júlio Marcelo de Oliveira traz a constatação que se segue: "A experiência histórica, entretanto, demonstrada empiricamente, revela que a indicação política permite a captura do órgão pelos grupos políticos dominantes, o que produz órgãos que tendem a ser lenientes, omissos ou menos rigorosos com os gestores integrantes desse grupo de domínio, sem falar no risco de corrupção no próprio tribunal, que não pode ser subestimado, como revelaram as operações da Polícia Federal Quinto do Ouro, Rodoleiros, Ararath e a própria operação Lava Jato, que deu início a investigação de alguns ministros do próprio TCU, suspeitos de participação em condutas criminosas. A indicação política, seja pelo Parlamento, seja pelo chefe do Poder Executivo, tem servido a algumas aberrações na composição dos tribunais de contas brasileiros. Há conselheiros sem curso superior. Outros com formação totalmente divergente do exigido, como odontologia. Há ainda as bizarras indicações de pessoas processadas por improbidade administrativa ou criminalmente por crimes contra a administração, até com condenação em segunda instância e há casos de compra de vaga de conselheiro mediante pagamento pela antecipação de aposentadoria de outro conselheiro, estando já acertado politicamente quem vai ocupar a cadeira de magistrado de contas. Quem se dispõe a pagar por vaga de conselheiro pretende obter retorno para seu criminoso investimento" (OLIVEIRA, Júlio Marcelo de. O papel dos órgãos de controle externo no combate à corrupção. Consultor Jurídico. 23 out. 2018. Disponível em: https://www.conjur.com.br/2018-out-23/papel-orgaos-controle-externo-combate-corrupcao. Acesso em: 25 jun. 2019). 
realizada por Audálio José Pontes Machado, até o ano de 2017, de um total de 186 Conselheiros existentes entre os Tribunais de Contas estaduais no Brasil, 126 (67,7\%) são de origem majoritariamente política, vindos de cargos eletivos ou de direção e assessoramento aos governos estaduais, 51 (27,5\%) eram servidores públicos e 9 (4,8\%) foram nomeados em função especialmente das relações familiares com governadores ou grandes famílias políticas dentro dos estados. Como conclui o autor, "as indicações políticas estão contidas nas regras do jogo".43

Em síntese, embora a gestão de uma instituição de relevância e porte como o TCU necessite de uma pluralidade em sua composição, que não reproduza exclusivamente e simplesmente conhecimentos técnicos, ${ }^{44}$ a forma como se tem feito a escolha dos seus membros (da mesma maneira como ocorre nos Tribunais de Contas subnacionais) torna duvidosa a sua imparcialidade. Os Tribunais de Contas, em razão de suas atribuições e competências constitucionalmente previstas, ocupam papel de destaque, devendo atuar de forma autônoma, independente, imune a pressões e ingerências de qualquer dos três Poderes, sob pena de se tornarem somente "departamentos submetidos ao interesse do Governo e, portanto, incapazes de fiscalizá-lo".45 Ainda que não fosse possível apontar nenhuma conduta dos membros do TCU indicadora de favorecimentos ou rigores excessivos em relação aos fiscalizados, em razão de seu passado político, a forma como de fato ocorrem as nomeações faz com que paire sobre a instituição uma desconfiança generalizada, desacreditando os trabalhos da Corte.

\subsection{Conclusões parciais}

Sob este primeiro escrutínio, referente à composição do TCU, observa-se que, na esfera do dever-ser, não há que se falar em um Tribunal necessariamente político. $O$ delineamento constitucional vigente, ainda que confira a escolha dos membros do TCU aos representantes do Legislativo e Executivo, o faz colocando requisitos mínimos, a semelhança do que ocorre com os Ministros do Supremo Tribunal Federal.

Veja que ao mesmo tempo que a Constituição não indica um perfil necessariamente político ao corpo de membros do TCU, também não impede que assim o seja. Desde que cumpridos os requisitos mínimos, não há nenhuma vedação a que os Ministros do TCU sejam ex-ocupantes de cargos políticos (ainda que essa situação não seja

\footnotetext{
43 MACHADO, Audálio José Pontes. Tribunais de Contas Estaduais: indicações, perfil dos conselheiros e autonomia das instituições. 2017. 82 f. Dissertação (Mestrado) - Curso de Ciência Política, Universidade Federal de Pernambuco, Recife, 2017, p.40.

44 CABRAL, Flávio Garcia. OTCU na Constituinte de 87-88: a estruturação da Corte de Contas. In: VIEIRA, Bruno Soeiro; OLIVEIRA, Frederico Antonio Lima de (Orgs.). Direito Público Contemporâneo: ensaios críticos. Volume II. Rio de Janeiro: Lumen Juris, 2017, p.188.

45 GUIMARÃES, Edgar. O controle das licitações pelos Tribunais de Contas. Fórum de Contratação e Gestão Pública - FCGP, Belo Horizonte, ano 5, n. 59, dez. 2006. Disponível em: <http://www.bidforum.com.br/bid/ PDI0006.aspx?pdiCntd=38550>. Acesso em: 10 jul. 2019.
} 
desejável, tendo em vista as críticas já lançadas no item precedente, em especial razão pelo fato de que serão os Ministros responsáveis por fiscalizar e julgar justamente, dentre outros, ocupantes de cargos políticos, pondo em xeque a imparcialidade e isenção no momento da tomada de decisões).

Quando se lança o olhar para a aplicação da norma constitucional, no âmbito do ser, a história constitucional brasileira evidencia, neste aspecto, o viés político do TCU. Ainda que não haja essa exigência constitucional, a grande maioria dos Ministros do TCU (cujo modelo acaba sendo seguido pelos Tribunais de Contas dos Estados) ocupava, anteriormente a sua indicação, cargos políticos, sendo praxe a nomeação pelo Congresso de seus pares para ocupar o cargo de Ministro.

\section{ANÁLISE QUANTO À ATUAÇÃO/FUNÇÃO DO TCU}

Existe um outro viés de análise a ser feito no que tange à aferição do caráter político ou não do Tribunal de Contas da União. Assim, pode-se falar, de outra maneira, se a função desempenhada pela Corte de Contas mostra-se política ou não.

Ao se referir ao exercício de uma função, na ordem jurídica ela é comumente trabalhada sob duas vestes ímpares (ainda que não incompatíveis): na primeira, indica certa espécie de poder; na segunda, reporta-se a uma forma de atividade. ${ }^{46}$

Sem prejuízo da possibilidade de convivência de ambas as acepções, para o Direito Administrativo contemporâneo, em particular no sistema jurídico brasileiro estruturado pela Constituição de 1988, o foco da função deve ser voltado com mais vigor para o exercício de uma atividade e não para o imaginário do poder. ${ }^{47}$

É nesse sentido então, da ideia de função se referindo à forma da atividade estatal, é dizer, à maneira pela qual o exercício das atribuições é desempenhado, ${ }^{48}$ que a indagação que se busca esclarecer é se existiria uma quarta função estatal, denominada de função política, que seria desempenhada pelo TCU.

\subsection{Função política ou de governo}

A criação de uma função tida como política ou de governo, ao lado das demais funções estatais estruturadas por Montesquieu (jurisdicional, legislativa e executiva), remete invariavelmente ao cenário francês.

Como narra Odete Medauar, a decisão mais célebre é o «arret Laffite", de maio de 1822, que tratava da seguinte questão: Napoleão havia concedido à Princesa Borghese

\footnotetext{
46 MODESTO, Paulo. Função Administrativa. Revista do Serviço Público, Brasília, v.46, n.2-3, mai./dez. 1995, p.101.

47 CABRAL, Flávio Garcia. O conteúdo jurídico da eficiência administrativa. Belo Horizonte: Fórum, 2019, p.189.

48 FRAGA, Gabino. Derecho administrativo. 40.ed. México: Porrúa, 2000, p.26.
} 
uma renda de 670.000 francos, que posteriormente foi transferida pela Princesa ao banqueiro Laffite; não pagas as rendas vencidas, desde o retomo dos Bourbons, uma Lei de janeiro de 1816 privou todos os membros da família Bonaparte dos bens havidos a título gratuito e entre estes a renda em questão; Laffite, que havia adquirido o crédito, depois de reclamar ao governo, ingressou com ação perante o Conselho de Estado, para que Ihe fossem pagas as rendas, ao menos até a data da lei de 1816. O Conselho de Estado deixou de apreciar o fundo da questão, alegando o seu caráter político. ${ }^{49}$

Outras sentenças do Conselho de Estado, do mesmo período, indicam o caráter político dos atos, podendo-se citar: "Duchesse de Saint Lieu" (1838), "Prince Louis" (1844), "Artentau" (1834)". Nessas decisões, os casos se referem, como regra, a medidas adotadas contra membros de antigas dinastias ou aplicação de convenções diplomáticas. No Segundo Império, tais sentenças estendem-se a outros campos: sequestro de livros e periódicos; fatos de guerra; medidas de segurança pública; medidas de polícia sanitária. ${ }^{50}$

Vê-se que o marco caracterizador dessa função estatal seria a impossibilida$\mathrm{de}^{51}$ do controle exercido pelo Poder Judiciário sobre certos atos praticados pelo Estado. Como aponta Paul Duez, em obra essencial sobre o assunto, o ato do governo implica a impossibilidade de o juiz controlar sua legalidade e, às vezes, de realizar sua interpretação. ${ }^{52}$

No mesmo sentido é a definição trazida por José Cretella Júnior, ao conceituar ato de governo ou ato político como toda "manifestação de vontade do poder público que, por sua condição toda especial, escapa à revisão do Poder Judiciário".53

Dentro dessa perspectiva, surgem teorias que buscam identificar que tipos de atos estariam abrangidos pela chamada função política ou de governo.

Assim, pode-se mencionar três principais teorias sobre a questão: a) Teoria do móvel político, segundo a qual os atos de governo seriam procedimento de alta política, cujas razões políticas não seriam passíveis de controle pelo Poder Judiciário ${ }^{54}$. Em outras palavras, fosse qual fosse o objeto material do ato, sempre que os governantes o ditassem em função de um fim político, o ato deixava de ser administrativo e se

49 MEDAUAR, Odete. Ato de governo. Revista de Direito Administrativo - RDA, Rio de Janeiro, n.191, jan./ mar. 1993, p.70.

50 MEDAUAR, Odete. Ato de governo. Revista de Direito Administrativo - RDA, Rio de Janeiro, n.191, p. 6785, jan./mar. 1993, p.70.

51 "La formulación de la teoría de la función gubernativa o de gobierno, ha dado lugar, por otro lado, a que se sostenga que todos os determinados actos de esa actividad, por su índole y naturaleza propia, están exentos de revisión judicial, sobre la base de la amplia discrecionalidad gubernativa que en ellos se ejerce, no puede ni debe ser sustituída por el juicio del Poder Judicial" (ESCOLA, Héctor Jorge. Compendio de Derecho Administrativo. Buenos Aires: Depalma, 1990. V.l, p.16).

52 DUEZ, Paul. Les actes de gouvernement. Paris: Dalloz, 2006, p.17.

53 CRETELLA JR., José. Teoria do ato de governo. Revista Inf. Legisl., Brasília, a.24, n.95, jul./set. 1987, p.73.

54 OLIVEIRA, Regis Fernandes de. Ato administrativo. 6.ed. São Paulo: Revista dos Tribunais, 2014, p.152-153. 
convertia em político, tornando-se, desta maneira, isento do controle contencioso-administrativo; ${ }^{55}$ b) Teoria da natureza ou lista jurisprudencial, que busca identificar uma natureza para os atos políticos ou de governo, utilizando-se como critério o estabelecimento de uma lista jurisprudencial de hipóteses nas quais haveria a função de governo, elaborada pelo Conselho de Estado. ${ }^{56}$ Tal teoria passa a ser seguida com o abandono da teoria do móvel político, que foi adotada até 1875, quando se estabeleceu o sistema de jurisdição delegada (desde 1872), reconhecendo ao Conselho de Estado sua total independência. Por conseguinte, houve o rechaço da teoria do móvel político no julgamento do caso conhecido por arrêt Prince Napoleón; ${ }^{57}$ c) Teoria da discricionariedade, no sentido de que a função política seria aquela exercida com "ampla discricionariedade", o que ocorreria em menor escala para os atos administrativos. ${ }^{58}$

\subsection{Compatibilidade com a ordem jurídica brasileira}

Apesar da origem francesa da função política ou governamental, certo é que esta construção acabou por ser incorporada por diversos doutrinadores de outros países, inclusive o Brasil $^{59}$ (ainda que com certas mudanças).

No entanto, ao menos atualmente, essa concepção de função de governo ou política tem sofrido rechaço por diversos autores brasileiros. Como se viu, as Constituições contemporâneas, ao consagrarem o princípio da inafastabilidade da apreciação jurisdicional a toda lesão de direito e ao reforçarem os meios de controle de

55 GARCÍA DE ENTERRÍA, Eduardo; FERNÁNDEZ, Tomás-Ramón. Curso de derecho administrativo. II. 9.ed. Madrid: Thomson Civitas, 2004, p.609.

56 OLIVEIRA, Regis Fernandes de. Ato administrativo. 6.ed. São Paulo: Revista dos Tribunais, 2014, p.153.

57 SANTOS NETO, João Antunes dos. Legalidade e decisões políticas. Revista de Direito Administrativo RDA, Rio de Janeiro, v.234, out./dez.2003, p.154.

58 OLIVEIRA, Regis Fernandes de. Ato administrativo. 6.ed. São Paulo: Revista dos Tribunais, 2014, p.154-155.

59 "Assim como ocorreu o fenômeno da absorção das declarações de direitos pelos textos constitucionais das nações tidas por civilizadas, a teoria da lista, decorrente da construção pretoriana originada do Conselho de Estado francês parece ter sido recepcionada pela mesma sistemática de assimilação em alguns países, em especial o Brasil" (SANTOS NETO, João Antunes dos. Legalidade e decisões políticas. Revista de Direito Administrativo - RDA, Rio de Janeiro, v.234, out./dez.2003, p.155). 
constitucionalidade, ${ }^{60}$ acabam por esvaziar as noções precedentes, impedindo a aplicação lesiva a situações subjetivas de particulares. ${ }^{61}$

Conforme expõe Ricardo Marcondes Martins, simplesmente inexiste função política ou de governo no Brasil. O que se chama "política", em Direito, é, na verdade, "discricionariedade", é dizer, a chamada função política ou de governo é o exercício discricionário, seja legislativo, seja administrativo ${ }^{62}$ (embora haja, por certo, diferenças significativas entre a discricionariedade legislativa e administrativa). ${ }^{63}$

Deveras, na medida em que a criação da chamada função política na França tem por pressuposto o afastamento do controle jurisdicional sobre certos atos praticados pelo Poder Executivo, tal concepção não encontra abrigo na sistemática constitucional brasileira. Sem a necessidade de se aprofundar muito o debate, o artigo $5^{\circ}$, inciso XXXV, parece espancar essa possibilidade, ao permitir o controle do Judiciário sobre qualquer ato que ocasione lesão ou ameaça de lesão a direito (sem colocar qualquer condicionante sobre a natureza do ato).

Há quem busque adequar a existência de uma função política à sistemática constitucional brasileira, como faz Regis Fernandes de Oliveira, por exemplo, que elimina o aspecto da insindicabilidade do ato pelo Poder Judiciário, e simplifica que função

60 Sobre a impossibilidade de determinados atos serem insindicáveis pelo Poder Judiciário, Rogério Gesta Leal apresenta as seguintes considerações: “Esse entendimento, com a máxima vênia, contraria frontalmente o sistema jurídico como um todo, notadamente a Constituição que, em nenhuma parte enuncia a vedação entrevista. Muito pelo contrário, consagra no art.5० XXXV, o princípio da inafastabilidade do controle judicial, e nos arts. 102, I, a; II, a e b; III, a, b e c; e 103, §2, o princípio da constitucionalidade dos atos estatais, ao dispor sobre os mecanismos assecuratórios da supremacia constitucional (pela ordem, a ação direta de inconstitucionalidade, o recurso ordinário, o recurso extraordinário, e a ação direta de inconstitucionalidade por omissão, aliando-se aqui o novel instituto da Ação de Descumprimento de Preceito Fundamental, regulamentada pela Lei Federal n 9.882/99, diploma regulador do art.102, parágrafo 1º da Constituição Federal de 1988, transcorridos já mais de 11 anos de sua entrada em vigor)" (LEAL, Rogério Gesta. Controle da administração pública no Brasil: anotações críticas. A\&C Revista de Direito Administrativo e Constitucional, Belo Horizonte, ano 5, n. 20, abr./jun. 2005, p.139).

61 MEDAUAR, Odete. Ato de governo. Revista de Direito Administrativo - RDA, Rio de Janeiro, n.191, p. 6785, jan./mar. 1993, p.85.

62 MARTINS, Ricardo Marcondes. "Políticas públicas" e Judiciário: uma abordagem neoconstitucional. A\&C Revista de Direito Administrativo \& Constitucional, Belo Horizonte, a. 18, n. 71, jan./mar. 2018, p.148.

63 O próprio autor esclarece que há 3 diferenças entre a discricionariedade legislativa e a administrativa: uma quantitativa e duas qualitativas. A quantitativa se apura no fato de o Legislador ter seu âmbito decisório restringido pelas normas constitucionais, enquanto o Administrador Público tem seu âmbito decisório restringido pelas normas constitucionais e legais. Há, portanto, um âmbito discricionário bem mais alargado no que tange à atividade legislativa. Do ponto de vista qualitativo, o sistema normativo imputa ao Administrador a escolha da melhor medida de concretização de um valor, o que restringe mais o âmbito de discricionariedade, enquanto que essa exigência não existe para o Legislador, que pode selecionar uma medida que seja somente proporcional, sem que seja a melhor. Por último, na discricionariedade administrativa os vícios de vontade do agente competente interferem na validade do ato, o que não ocorre na função legislativa (MARTINS, Ricardo Marcondes. Teoria dos princípios e função jurisdicional. Revista de Investigações Constitucionais, Curitiba, vol. 5, n. 2, mai./ago. 2018, p.138-139). 
política seria aquela que é referente à expedição de atos pelo Presidente da República e que independem de intermediação legislativa. ${ }^{64}$

De maneira semelhante, encontra-se em Celso Antônio Bandeira de Mello que determinados atos não se enquadrariam nem na função legislativa, nem na função administrativa ${ }^{65}$ (como a sanção ou veto a projeto de lei pelo Poder Executivo, a declaração de estado de sítio ou a destituição de altas autoridades por crime de responsabilidade). Seriam atos de superior gestão da vida estatal, que se enquadrariam melhor como sendo exercidas na função política ou de governo (mas sem as consequências que a doutrina europeia Ihe atribui). ${ }^{66}$

Não obstante as colocações dos juristas acima mencionados, não há porque distinguir, na sistemática jurídica brasileira, as funções política ou de governo, pelo simples fato de que não há qualquer consequência útil e/ou relevante que decorra dessa nomenclatura.

A criação de um aparte entre a função administrativa e uma denominada função política, como visto previamente, era isentar a segunda do controle judicial. A partir do momento em que se apura a impossibilidade de se evitar o controle pelo Poder Judiciário, os efeitos significativos desta diferenciação perdem seu sustentáculo. Trata-se de uma nomenclatura que não é capaz de indicar nenhum traço característico que seja indicativo de efeitos relevantes ou, com mais razão, de um regime jurídico diferenciado.

Seguindo esta linha, de que não haveria uma verdadeira função política ou de governo no Direito brasileiro, ao se analisar o TCU é possível observar que ele exerce, em realidade, a função administrativa, não cabendo Ihe atribuir uma quarta função.

De fato, conforme aponta Ricardo Marcondes Martins, a redação do artigo $2^{\circ}$ da Constituição brasileira indica a utilização da teoria da separação dos Poderes de Montesquieu, sendo que todas as funções estatais se referem a uma das três funções clássicas (administrativa, legislativa e jurisdicional). ${ }^{67}$ Logo, as funções exercidas pelo Ministério Público e Tribunal de Contas, na ordem jurídica brasileira, devem se enquadrar em alguma das três (ainda que formalmente não estejam enquadrados na estrutura

64 OLIVEIRA, Regis Fernandes de. Ato administrativo. 6.ed. São Paulo: Revista dos Tribunais, 2014, p.170. Odete Medauar indica essencialmente os mesmos traços característicos dos atos de governo (MEDAUAR, Odete. Ato de governo. Revista de Direito Administrativo - RDA, Rio de Janeiro, n.191, p. 67-85, jan./mar. 1993, p.81).

65 É o mesmo critério usado por André Luiz Freire. Segundo o autor, embora não se possa sustentar a função política no Brasil como sendo aquela insindicável, seria possível atribuir-lhe um regime jurídico diferenciado, uma vez que ela não se identifica com as demais funções estatais (não inova na ordem jurídica; não tem caráter de definitividade; nem é exercida em uma estrutura e regime hierárquico nem é infralegal). Seus pontos diferenciadores seriam, para ele, o fato de os atos políticos virem diretamente da Constituição (sem intermediação legislativa) e serem exercidos com discricionariedade (FREIRE, André Luiz. Apontamentos sobre as funções estatais. Revista de Direito Administrativo - RDA, ano 13, n. 248, mai./ ago. 2008, p.47-48).

66 BANDEIRA DE MELLO, Celso Antônio. Curso de direito administrativo. 33.ed. São Paulo: Malheiros, 2016, p.37.

67 MARTINS, Ricardo Marcondes. Efeitos dos vícios do ato administrativo. São Paulo: Malheiros, 2008 , p.42. 
hierárquica e administrativa de nenhum deles). Tendo em vista que estes órgãos não exercem atividades de julgamento com caráter de definitividade (função jurisdicional), ${ }^{68}$ nem inovam no ordenamento jurídico com atos normativos primários (função legislativa), por certo que suas condutas se adequam ao exercício da função administrativa.

Além disso, em total afastamento das consequências trazidas pela doutrina francesa, os atos praticados pelo TCU são controláveis pelo Poder Judiciário (dentro dos limites de controle exercidos por este Poder). É desta forma, inclusive, que a então Ministra do STF, Ellen Gracie, posiciona-se quando assegura que o controle externo da atividade contábil, financeira, orçamentária, operacional e patrimonial da União e das entidades da administração direta e indireta quanto à legalidade, legitimidade, economicidade, aplicação das subvenções e renúncia de receitas (art. 70 da Constituição), a cargo do Congresso Nacional e exercido com o auxílio do tribunal de Contas (art. 71 da Constituição), sujeita-se ordinariamente ao mesmo regime de controle judicial. ${ }^{69}$

A função política poderia, ainda, ser compreendida como sinônima ou fortemente relacionada à função legislativa. ${ }^{70}$ Esta, segundo um critério objetivo formal, seria a que inova primariamente na ordem jurídica. ${ }^{71} \mathrm{Ou}$ seja, o que diferiria a função política (legislativa) da administrativa seria, essencialmente, a possibilidade de inovação no ordenamento jurídico, atribuída à primeira e não à segunda. Nesta vertente, como a função exercida pelo TCU é administrativa, como visto acima, não inovando primariamente na ordem jurídica, a Corte igualmente não desempenha função política nessa conotação.

De outra banda, o vocábulo "político", no que diz respeito ao desempenho de uma função, pode se referir à prática de atos no exercício da competência discricionária. ${ }^{72}$ Aqui, por certo, é evidente que o TCU exerce certos atos no desempenho de competências discricionárias.

68 Há autores que encaram o exercício da competência constitucional prevista no artigo 71, inciso ll, do texto constitucional como representante do exercício atípico da função jurisdicional. Nessa trilha, Jorge Ulisses Jacoby Fernandes sustenta que "no atual modelo constitucional positivo, ficou indelevelmente definido o exercício de função jurisdicional pelos Tribunais de Contas" (FERNANDES, Jorge Ulisses Jacoby. Tribunal de Contas do Brasil: jurisdição e competência. 2.ed. Belo Horizonte: Fórum, 2008, p.147). Entretanto, na maneira pela qual se defende neste artigo, a atuação das Cortes de Contas com base no artigo 71, inciso II, não tem a aptidão de produzir a chamada "coisa julgada", não possuindo, pois, o atributo da definitividade, ínsita à função jurisdicional.

69 GRACIE, Ellen. Notas sobre a revisão judicial das decisões do Tribunal de Contas da União pelo Supremo Tribunal Federal. Revista TCU, Brasília, a.38, n.110, set./dez. 2007, p.8.

70 PIVETTA, Saulo Lindorfer. Legisladores juízes: Impeachment na Constituição de 1988. 2017. 322 f. Tese (Doutorado) - Curso de Direito, Universidade Federal do Paraná - Ufpr, Curitiba, 2017, p.213.

71 BANDEIRA DE MELLO, Celso Antônio. Curso de direito administrativo. 33.ed. São Paulo: Malheiros, 2016, p.33.

72 Neste sentido, Ricardo Marcondes Martins: "O que caracteriza os chamados atos políticos ou de governo é o fato de serem decorrentes do exercício de competência discricionária. Em Direito, a política é nada mais nada menos do que discricionariedade" (MARTINS, Ricardo Marcondes. "Políticas públicas" e Judiciário: uma 
Sem embargo, a discricionariedade conferida ao TCU não é tão ampla quanto a que possui o Poder Legislativo ${ }^{73}$ na sua função típica. Os parâmetros de controle atribuídos pela Constituição Federal, como legitimidade e economicidade (artigo 70, caput), por exemplo, embora possam conferir algum grau de discricionariedade decisória, inerente de conceitos jurídicos indeterminados, sempre acarretarão uma subjetividade limitada pela Constituição e pela legislação de regência, seja do próprio TCU (vide a Lei Orgânica n 8.443/92), seja a legislação pertinente ao exercício da função administrativa que está sendo exercida (o regramento da Lei no 8.666/93, e.g., no caso de análise de processos licitatórios). Ademais, estes próprios critérios possuem cunho jurídico, é dizer, ao decidir com base neles, desde que dentro de seus limites, está-se atendendo ao Direito posto.

O Tribunal não possui, e isso precisa ficar claro, liberdade para decidir em desconformidade com o Direito, ${ }^{74}$ por razões subjetivas de seus membros, por uma busca de uma decisão "mais justa"75 ou mesmo com base em uma discricionariedade ampla (política). ${ }^{76}$

Com a mesma intelecção, ao discorrer sobre o controle feito pelo TCU em relação aos contratos administrativos, Carlos Ari Sundfeld, Jacintho Arruda Câmara, Vera Monteiro e André Rosilho explicam que as manifestações da Corte não podem ser classificadas como tecnicamente discricionárias ou mesmo como decisões discricionárias de mérito administrativo. Segundo os autores, todos os aspectos envolvidos em sua deliberação dizem respeito à avaliação quanto à juridicidade da formação e da execução dos contratos, uma vez que o TCU não atua de maneira discricionária quando aprova ou

abordagem neoconstitucional. A\&C - Revista de Direito Administrativo \& Constitucional, Belo Horizonte, a. 18, n. 71, jan./mar. 2018, p.149).

73 Como já visto, a margem de apreciação do Poder Legislativo é mais ampla, uma vez que somente se vincula à própria Constituição, enquanto que, no exercício da função administrativa, há a vinculação à Constituição e à legislação infraconstitucional (MARTINS, Ricardo Marcondes. Proporcionalidade e boa administração. Revista da Faculdade de Direito PUC/SP, v.3, n.1, $1^{\circ}$ sem. 2015, p.335).

74 A afirmação de que oTCU não tem discricionariedade ampla para decidir à margem do Direito não significa necessariamente que, de fato, ele não o faça. No entanto, a investigação da atuação do TCU nesse sentido, em uma espécie de um verdadeiro "ativismo de contas", demanda uma pesquisa autônoma e aprofundada, que não encontra espaço no presente artigo.

75 A respeito dos "heróis" e "justiceiros", frequentemente encontrados em determinados órgão públicos, que buscam desviar os ditames normativos em benefício de uma pretensa justiça, Emerson Gabardo bem assinala que "a 'ilusão da justiça' é uma decorrência da falsa percepção de que os agentes públicos podem, a partir de uma consciência pura, austera e imparcial, refletir os anseios de felicidade dos demais indivíduos para além de uma ordem deliberada e a priori estabelecida como regra geral objetiva" (GABARDO, Emerson. Os perigos do moralismo político e a necessidade de defesa do direito posto na Constituição da República de 1988. A\&C Revista de Direito Administrativo \& Constitucional, Belo Horizonte, a. 17, n. 70, out./dez. 2017, p.85).

76 Tendo em que dentre as atribuições do TCU se destaca as competências punitivas, cabíveis são as constatações de Saulo Lindorfer Pivetta, para quem a Constituição de 1988 não admite a imputação de sanções a partir de juízo político ou discricionário, garantia que se aplica de maneira forte a qualquer processo punitivo. (PIVETTA, Saulo Lindorfer. Legisladores juízes: Impeachment na Constituição de 1988. 2017. 322 f. Tese (Doutorado) - Curso de Direito, Universidade Federal do Paraná - Ufpr, Curitiba, 2017, p.297). 
rejeita uma contratação, tendo em vista que não Ihe foi dada competência para rejeitar ou aprovar um contrato por motivos de conveniência ou oportunidade. Em síntese, a decisão do TCU é (deve-ser) estritamente técnico-jurídica. ${ }^{77}$

Logo, o espectro decisional conferido ao TCU não é político (no sentido de uma discricionariedade total), mas sim balizado pelas normas jurídicas.

\subsection{Conclusões parciais}

No que concerne ao caráter das funções desempenhadas pelo TCU, não se apura o exercício de uma função política. Isso ocorre porque, à luz do ordenamento jurídico brasileiro vigente, não haveria, por nenhum órgão ou entidade, o exercício de uma função política ou de governo (no sentido atribuído na construção doutrinária francesa), já que, dentro dos limites constitucionais, todos os atos praticados pelo TCU estariam sujeitos, em maior ou menor medida, a um controle pelo Poder Judiciário.

Ainda para os que entendam existir uma função política, havendo quem a limite, como Regis Fernandes de Oliveira, ${ }^{78}$ a certas atribuições desempenhadas somente pelo Chefe do Poder Executivo, ou mesmo a atividades de gestão superior do Estado brasileiro, de igual sorte o TCU não desempenharia tal função. Ao se entender função política como sinônima de função legislativa, a Corte de Contas igualmente não exerce atos políticos, já que não inova primariamente na ordem jurídica.

Por outro lado, acerca do termo político como relacionado ao exercício de competências discricionárias, ainda que o órgão de controle pratique eventualmente atos tidos por discricionários, como ocorre em qualquer órgão da Administração Pública, suas decisões devem ser todas pautadas dentro dos moldes conferidos pelo Direito, não havendo uma total ou ampliada liberdade (aspecto político) ao órgão de controle, que possui limites evidentes traçados pela Constituição e pela legislação. Não há, pois, como chamá-lo de político sob esta perspectiva.

\section{ANÁLISE QUANTO À INFLUÊNCIA DO E SOBRE O TCU}

Um ponto derradeiro de investigação sobre o viés político ou não do TCU diz respeito à influência política que sofre ao exercer suas atribuições, bem como seu papel e conduta ao influenciar a tomada de decisões políticas. ${ }^{79}$

77 SUNDFELD, Carlos Ari; CÂMARA, Jacintho Arruda; MONTEIRO, Vera; ROSILHO, André. O valor das decisões do Tribunal de Contas da União sobre irregularidade em contratos. Revista Direito GV, v.13, n.3, set./dez. 2017, p.882.

78 OLIVEIRA, Regis Fernandes de. Ato administrativo. 6.ed. São Paulo: Revista dos Tribunais, 2014, p.170.

79 Esse último sentido seria relacionado ao que Saulo Lindorfer Pivetta chama de "política competitiva", isto é, a dimensão em que a política se manifesta como um "jogo", praticada a partir de articulações e permeada por conflitos e alianças, por vezes desconsiderando possíveis limites jurídicos (PIVETTA, Saulo Lindorfer. 
Trata-se de dois aspectos distintos, que podem convergir ou não. De um lado, refere-se a saber se o TCU exerce suas atribuições alheio a qualquer influência política externa, sem que interesses políticos tenham algum peso na sua análise técnica. Do outro, diz respeito a se o TCU participa das pautas políticas, interferindo, em maior ou menor medida, na atuação legislativa, direcionando (ou buscando direcionar) os rumos das decisões governamentais.

\subsection{O parecer das contas públicas (Artigo 71, I)}

Dentre todas as competências constitucionais atribuídas ao Tribunal de Contas da União, a que talvez tenha maior relevância e destaque seja a apreciação anual das contas do governo (artigo 71, inciso I, da CF). De fato, sua importância é enfatizada pelos próprios membros da Corte de Contas, podendo-se invocar a escrita do Ministro Paulo Affonso Martins de Oliveira, no introito da apreciação das contas de 1991, a qual destaca que esse parecer é da mais elevada atribuição conferida à Corte de Contas pela Constituição Federal, acrescida pela repercussão que atos dessa natureza geram em todos os níveis da Administração Pública.80

Em igual sentido, com um olhar externo dos quadros do TCU, Bruno Wilhelm Speck aduz que "a elaboração de um parecer prévio sobre as contas do governo há longo tempo é o principal mecanismo de interação entre Legislativo e Tribunal de Contas".81

Sem embargo, essa atribuição talvez seja a mais problemática na rotina do TCU, pelo menos no que se refere a um controle horizontal efetivo.

A agrura repousa no fato de que em toda a história da Corte de Contas da União, isso é, desde sua criação em 1890 até 2019, praticamente (com raras exceções) todas as contas de governo foram consideradas nos pareceres do TCU, como aptas a serem aprovadas. Como afirma Charles Pessanha sobre essa atribuição da Corte, "os resultados desse processo ao longo do tempo [...] vêm frustrando as expectativas".82

Para ser mais preciso, traz-se algumas breves considerações sobre anos específicos. Assim, em realidade, ademais de algumas manifestações em anos mais recentes, houve um ano nesses mais de um século de história em que houve a manifestação do TCU pela reprovação das contas do chefe do Poder Executivo: foi em 1937, ao se

\footnotetext{
Legisladores juízes: Impeachment na Constituição de 1988. 2017. 322 f. Tese (Doutorado) - Curso de Direito, Universidade Federal do Paraná - Ufpr, Curitiba, 2017, p.297).

80 TRIBUNAL DE CONTAS DA UNIÃO. Relatório e parecer prévio sobre as contas do governo da república. Brasília:TCU, 1991, p.11.

81 SPECK, Bruno Wilhelm. Inovação e rotina no Tribunal de Contas da União: o papel da instituição superior de controle financeiro no sistema político-administrativo do Brasil. São Paulo: Fundação Konrad Adenauer, 2000, p.96.

82 PESSANHA, Charles. O Congresso Externo sob o controle das contas. Insight Inteligência, Rio de Janeiro, n.21, abr./mai./jun. 2002, p.126.
} 
analisar as contas do exercício de 1936, do então Presidente Getúlio Vargas. Contudo, sentindo o peso do autoritarismo de Vargas, essa manifestação pelo TCU obteve duas consequências. A primeira foi que a Câmara dos Deputados - responsável pelo efetivo julgamento das contas à época -, por meio do Decreto Legislativo n 101/1937, contrariando o parecer do Tribunal, declarou as contas aprovadas. A segunda é que pouco tempo depois o Ministro relator das indigitadas contas, Francisco Thompson Flores, viria a ser posto em disponibilidade, não mais retornando ao TCU. ${ }^{83}$

Outro ano que chama atenção, e que talvez represente o caráter político então investigado, remete à gestão de Fernando Collor de Mello, que acabou sendo destituído do cargo em razão do processo de impeachment. Em relação ao exercício de 1991, ano marcado por um conturbado momento político e gerencial, havendo denúncias sobre possíveis escândalos de corrupção envolvendo o Presidente, o Tribunal de Contas da União, por meio do Ministro-relator Paulo Affonso Martins de Oliveira esclareceu que não cabe à Corte julgar as contas prestadas pelo Presidente da República, por se tratar de competência exclusiva do Congresso Nacional. Nessa linha de raciocínio, concluiu o TCU ${ }^{84}$ que não competiria ao parecer indicar a reprovação ou aprovação (ainda que com ressalvas) das contas, tendo elaborado, então, um documento, que se pretendia parecer - embora não opinativo -, no sentido de que as contas somente seriam aptas a serem apreciadas pelo Congresso. ${ }^{85}$

Da mesma maneira, quanto às contas do ano seguinte (1992), ante o quadro político ora iluminado, encontrou-se, tal como ocorrido em 1990, embora por razões distintas, dividida em duas gestões, sendo a primeira de $1^{\circ}$ de janeiro a 29 de setembro de 1992 (Fernando Collor de Mello) e 30 de setembro a 31 de dezembro do mesmo ano (Itamar Franco). Este ano, marcado por desconformidades tão gritantes, que não poderiam passar desapercebidas pelo TCU, obteve manifestação de um único Ministro, ${ }^{86}$ Fernando Gonçalves, pela reprovação no período de gestão do então presidente Fernando Collor de Mello. Os demais Ministros sustentaram, em síntese, que as contas

83 SILVA, Artur Adolfo Cotias e. O Tribunal de Contas da União na História do Brasil: evolução histórica, política e administrativa (1890-1998). Prêmio Serzedello Corrêa 1998: Monografias Vencedoras. Brasília: TCU - Instituto Serzedello Corrêa, 1999, p.74.

84 Há que se ressalvar que os Ministros Fernando Gonçalves e Élvia L. Castello Branco se posicionaram contrários a esse "parecer" inconclusivo. O primeiro inclusive suscitou uma preliminar (que foi rejeitada), argumentando o seguinte: "Da mesma forma, este Tribunal, ao emitir o Parecer Prévio sobre as contas do governo, para embasar o julgamento a cargo do Congresso Nacional, deve dizer se as contas merecem ou não ser aprovadas. De outro modo, seria levar a Corte ao esvaziamento que tanto combatemos, seria uma atitude inócua, porque não teria cumprido sua missão constitucional".

85 CABRAL, Flávio Garcia. O Tribunal de Contas da União na Constituição Federal de 1988. São Paulo: Verbatim, 2014, p.162-166.

86 O Ministro Homero Santos também abordou a questão, assentando que se o exercício tivesse sido inteiramente presidido por Collor, sua manifestação seria pela reprovação, mas como havia uma cisão de gestões, vindo Itamar Franco a assumir o fim daquele período, as contas deveriam, na sua opinião, ser analisadas de modo global, optando, portanto, por seguir a linha do relator e se manifestar pela aprovação. 
deveriam ser analisadas de maneira global, logo não caberia reprová-las tendo em vista a ausência de irregularidades graves no período da gestão do Presidente Itamar Franco. Como defendeu o Ministro relator, "não se pode e nem se deve estabelecer qualquer marco divisório entre eles, vez que as virtudes nominadas ou os defeitos identificados se constituíram em um 'continuum', sem que se possa precisar uma demarcação de quando tiveram início ou fim". ${ }^{87}$ Assim, a apreciação deu-se de forma global, uma vez que, segundo o relator, "a prestação de contas do Presidente da República não é, pois, uma justaposição ou agregado de contas de agentes públicos específicos".88

Extrai-se de uma análise detalhada sobre anos pós-1988 acerca do parecer prévio sobre as contas do governo que, "não obstante a ordem jurídica vigente tenha conferido instrumentos normativos para que o TCU possa 'ter dentes e morder', o próprio Tribunal teme a utilização de seus dentes, com nítido receio de 'desapontar' quem deveria ser punido".89

O que se vinha tendo até então era uma aprovação, quase que automática das contas do governo, que acabava por transformar a apreciação das contas anuais (que deveria ser ponto alto da atuação do TCU) em um singelo expediente obrigatório, mas de valor material pouco relevante.

Afinal, uma eventual reprovação das contas do governo pelo TCU não seria uma afronta apenas ao Presidente da República e demais membros do governo (o que, por si só, já evidencia o turbilhão de complicações políticas que teriam que enfrentar os membros do Tribunal), mas de igual forma encaminharia ao Poder Legislativo a responsabilidade de rejeitar as contas (sendo que na atual configuração política de alianças partidárias teria o condão de dificultar as empreitadas políticas de muitos dos seus membros) ou de demonstrar à sociedade civil o motivo de refutar as razões apresentadas pelo TCU (o que poderia manchar a imagem do próprio Congresso Nacional e de seus membros). Com entendimento semelhante, Pedro Roberto Decomain analisou que caso o Tribunal de Contas demonstrasse a existência de irregularidades nas contas do Executivo e sugerisse ou recomendasse, em seu parecer prévio, que elas fossem rejeitadas pelo Legislativo, este poderia vir a ser chamado pela população a por sua vez prestar-lhe satisfações quando, a despeito disso, decidisse aprová-las. Assim, aprovações de contas cuja rejeição, porque irregulares, foi recomendada pelo Tribunal

\footnotetext{
87 TRIBUNAL DE CONTAS DA UNIÃO. Relatório e parecer prévio sobre as contas do governo da república. Brasília:TCU, 1992, p.9.

88 TRIBUNAL DE CONTAS DA UNIÃO. Relatório e parecer prévio sobre as contas do governo da república. Brasília:TCU, 1992, p.9.

89 CABRAL, Flávio Garcia. O Tribunal de Contas da União na Constituição Federal de 1988. São Paulo: Verbatim, 2014, p.225.
} 
de Contas, podem comprometer a imagem do Poder Legislativo e eventualmente até mesmo de integrantes seus, perante a população. ${ }^{90}$

Não obstante, o agir mais recente do TCU indica um novo comportamento do Tribunal (ainda que os seus principais fundamentos pareçam continuar sendo as pressões externas). Isso porque, contrariando seu padrão histórico, em relação às contas presidenciais dos exercícios de 2014 e 2015, ambas referentes ao governo de Dilma Roussef, manifestou-se o Tribunal, de maneira unânime, por meio dos pareceres prévios, pela sua reprovação.

Não se pode, contudo, ignorar justamente o momento político, econômico e social no qual o Brasil se encontrava, que em muito favoreceu para que o Tribunal tomasse essas decisões (o cenário vigente demonstrava que justamente a reprovação das contas foi pautada, mais uma vez, por fortes influências políticas), sem considerar possíveis influências externas de partidos de oposição e da imprensa.

\subsection{Os trabalhos legislativos}

Acerca da possível influência, direta ou indireta, que o TCU exerce nos rumos governamentais e legislativos no Brasil, de modo a ilustrar a situação, sem que a análise esgote a questão, mas que serve como um forte indicativo do comportamento da Corte, serão trabalhados dois casos que se encontram situados em dois extremos temporais no momento constitucional: primeiro, ver-se-á a atuação do TCU nos trabalhos da Constituinte de 87-88. Posteriormente, apontar-se-ão manifestações do TCU em relação ao projeto de Lei n 7.448/2017, que acarretou na recente alteração legislativa da LINDB.

\subsubsection{A constituinte de $87-88$}

A elaboração de uma nova Constituição, em especial após um período marcado por um regime de exceção explícito no Brasil, trouxe à tona debates pertinentes as mais variadas áreas e aspectos da sociedade brasileira. Nesta toada, ainda que de forma mais contida, se considerado o destaque conferido a outros temas e a relevância que possui o controle externo das finanças públicas, o Tribunal de Contas tornou-se tópico objeto de inúmeros debates nos trabalhos da Constituinte.

Cabe lembrar que o Tribunal de Contas da União foi inserido em alguns artigos esparsos do anteprojeto constitucional, elaborado pela Comissão Provisória de Estudos Constitucionais (denominada "Comissão Afonso Arinos"), instituída pelo Decreto n. 91.450/85. Assim, a primeira menção ao TCU repousou justamente no que concerne à

90 DECOMAIN, Pedro Roberto. Tribunais de Contas no Brasil. São Paulo: Dialética, 2006, p.79. 
sua denominação, uma vez que o artigo 18 do referido anteprojeto propunha a alteração do nome Tribunal de Contas da União para Tribunal Federal de Contas. ${ }^{91}$

Não obstante não ter havido um encaminhamento oficial do Anteprojeto da Comissão Afonso Arinos ${ }^{92}$, o seu texto serviu de base para os trabalhos constituintes, tendo sido de fundamental importância para o desenrolar da Constituição de 1988. Os trabalhos versando em torno do TCU foram atribuídos, em um primeiro momento, especialmente à Subcomissão de Orçamento e Fiscalização Financeira. ${ }^{93}$

Dessarte, um dos pontos nevrais nos trabalhos da Constituinte, no que concerne ao Tribunal de Contas da União, como não podia deixar de ser, referiu-se à escolha e garantia da vitaliciedade de seus membros.

Assim, as propostas versando sobre os membros do TCU foram apresentadas já na fase de deliberação das Subcomissões, na qual o constituinte Jessé Freire, além de sugerir, em debate aberto, a alteração do nome do Tribunal, como já aventado anteriormente, também se manifestou no sentido de alterar os critérios de escolha dos ministros do TCU, sugerindo que ela recaísse sobre cidadãos maiores de 35 anos, com notório saber jurídico, de finanças ou econômico, mas que fossem aprovados em concurso público de provas e títulos. Sua justificação girou essencialmente em torno da garantia da autonomia e independência dos Ministros. ${ }^{94}$

91 Nos trabalhos da Constituinte não houve debates mais acirrados acerca da eventual alteração do nome do TCU para Tribunal Federal de Contas, salvo, dentre algumas, da proposta do constituinte Jessé Freire, durante a fase das deliberações nas Subcomissões Temáticas, onde aquele alvitrou: "A proposta do Projeto Constituição Affonso Arinos tem, no seu bojo, a mudança do nome Tribunal da União para Tribunal Federal de Contas. Por conseguinte, esta é também a minha proposta: onde se lê: 'Tribunal de Contas da União', leia-se 'Tribunal Federal de Contas'"' (ASSEMBLEIA NACIONAL CONSTITUINTE. Comissão do Sistema Tributário, Orçamento e Finanças. Subcomissão de Orçamento e Fiscalização Financeira. Ata da 9a Reunião Ordinária (14/05/87). Brasília: Centro Gráfico do Senado Federal, 1987-1988, p.65). Todavia, os constituintes ignoraram a proposta, mantendo a nomenclatura Tribunal de Contas da União, em vigor até a presente data.

92 Sobre o não encaminhamento do Anteprojeto da Comissão Afonso Arinos, o senador José Sarney, Presidente da República à época dos fatos, justificou que assim o fez para evitar uma crise institucional, pois "Ulysses Guimarães, presidente da Assembléia Nacional Constituinte, Ihe havia avisado que devolveria o texto caso o recebesse". No mesmo sentido, o senador Cristovam Buarque também acrescentou que "de fato, houve uma pressão muito grande, por parte de muitos constituintes, para que o anteprojeto não chegasse ao Congresso; eles consideravam o texto uma intromissão do Executivo em seus trabalhos" (KOSHIMIZU, Ricardo Koiti. Comissão Afonso Arinos elaborou anteprojeto de Constituição. Agência Senado, Brasília, 01 out. 2008. Disponível em: <http://www.senado.gov.br/noticias/comissao-afonso-arinos-elaborou-anteprojeto-de-constituicao. aspx>. Acesso em: 10 ago. 2011).

93 As fases de funcionamento da Constituição foram, em síntese, as seguintes: a) fase preliminar, com a definição do Regimento Interno da Assembleia Nacional Constituinte e colheita de sugestões de entidades, cidadãos e constituintes; b) fase das Subcomissões Temáticas; c) fase das Comissões Temáticas; d) fase da Comissão de Sistematização; e) fase de Plenário (com votação em dois turnos); e f) fase de Comissão de Redação.

94 "Acho fundamental que os membros do Tribunal Federal de Contas tenham a independência e autonomia necessária, através de concurso público e de critérios objetivos - e não subjetivos -, para que esses senhores tenham condições, então, de, com autoridade, com vigilância, com total independência, exercer suas funções. Não quero dizer absolutamente que atualmente isso não exista; acredito que sim, mas apenas, com toda a certeza, é através do concurso público que conseguiremos uma maior nitidez da atuação do Tribunal Federal de Contas e de seus membros" (ASSEMBLEIA NACIONAL CONSTITUINTE. Comissão do Sistema Tributário, 
O constituinte Messias Góis ${ }^{95}$ se opôs à realização de concurso público para nomeação dos membros da Corte de Contas da União, esclarecendo, inicialmente, que em nenhum tribunal superior do país haveria concurso público para provimento de seus integrantes, não devendo ser diferente com TCU. Ademais, por uma questão de praticidade e economia, entendeu aquele parlamentar que a realização de um concurso cada vez que um dos ministros se aposentasse seria algo impraticável.

Outro ponto que restou consignado nos trabalhos da subcomissão, desta vez sem maiores entraves, refere-se à vitaliciedade dos membros do TCU, onde, de forma ilustrativa, ambos os constituintes citados, Jessé Freire e Messias Góis. Manifestaram-se pela manutenção desta garantia.

Importante questão relacionada à subcomissão em referência remete à participação de membros do TCU durante as audiências públicas ${ }^{96}$ que ali ocorreram. Com poucas audiências realizadas nesta subcomissão (um total de 6), encontraram-se presentes em uma ocasião o então Presidente do TCU, Fernando Gonçalves (28/04/1987), e, posteriormente, aquele mesmo membro do Tribunal acompanhado dos também Ministros da Corte, Alberto Hoffmann e Ewald Sizenato Pinheiro (06/05/1987). ${ }^{97}$

A contribuição dos Ministros do Tribunal de Contas aos trabalhos da subcomissão foi além dos esclarecimentos prestados aos parlamentares acerca da atividade fiscalizatória da Corte, tendo o Ministro Alberto Hoffmann, conforme já anunciado na audiência de 28/04/1987, apresentado em 06/05/1987 uma minuta de redação do texto constitucional referente ao controle orçamentário. Dentre as novidades trazidas pela aludida minuta, destaca-se a proposta do controle estatal ser repartido em três

Orçamento e Finanças. Subcomissão de Orçamento e Fiscalização Financeira. Ata da 9a Reunião Ordinária (14/05/87). Brasília: Centro Gráfico do Senado Federal, 1987-1988, p.65-66).

95 ASSEMBLEIA NACIONAL CONSTITUINTE. Comissão do Sistema Tributário, Orçamento e Finanças. Subcomissão de Orçamento e Fiscalização Financeira. Ata da 9a Reunião Ordinária (14/05/87). Brasília: Centro Gráfico do Senado Federal, 1987-1988, p.66.

96 Sobre as audiências públicas que ocorreram durante os trabalhos da Constituinte, Ana Luiza Backes, Débora Bithiah de Azevedo e José Cordeiro de Araújo esclarecem: "As 24 Subcomissões da Assembleia Nacional Constituinte, instaladas em 7 de abril de 1987, iniciaram as reuniões de audiência pública a partir de do mesmo mês e começaram a discutir seus relatórios em meados do mês de maio. Portanto, em torno de apenas três semanas, foram realizadas as cerca de 200 reuniões, sendo ouvidos, simultaneamente, os mais diferentes setores da sociedade brasileira. Ao longo desses dias intensos, quase 900 pessoas - representantes de organizações da sociedade civil, acadêmicos, órgãos governamentais, juristas e outros - ocuparam todas as tribunas do Congresso, apresentaram centenas de propostas, polemizaram em torno dos principais temas em discussão, debateram com os constituintes, demarcaram campos e objetos de disputa política. O Parlamento foi tomado por delegações de todo o Brasil, abrindo espaço para múltiplas vozes" (BACKES, Ana Luiza; AZEVEDO, Débora Bithiah de; ARAÚJO, José Cordeiro de. Introdução. In: BACKES, Ana Luiza et al (orgs.). Audiências públicas na Assembleia Nacional Constituinte: a sociedade na tribuna. Brasília: Câmara dos Deputados, 2009, p.14).

97 HELENA, Eber Zoehler Santa. V.b-Subcomissão Orçamentária e Fiscalização Financeira. In: BACKES, Ana Luiza et al (orgs.). Audiências públicas na Assembleia Nacional Constituinte: a sociedade na tribuna. Brasília: Câmara dos Deputados, 2009, p.340. 
instâncias, quais sejam o controle interno (pela Administração Pública), o controle congressual (pelo Legislativo) e o controle externo (pelo Tribunal de Contas). ${ }^{98}$

Muito embora aquela inovação não tenha sido acolhida pela subcomissão ao final dos trabalhos, percebe-se que a interferência dos membros do TCU mostrou-se relevante, uma vez que a minuta apresentada serviu como norte para a redação do anteprojeto da subcomissão. Desta sorte, Eber Zoehler Santa Helena demonstra que toda a seção IX, que trata da fiscalização contábil, financeira e orçamentária recebeu considerável influência da minuta apresentada pelo TCU na audiência de 6/5/1987, exceto pela pretensão da Corte de Contas em criar uma nova modalidade de controle externo, ao propor a existência de três formas de controle (congressual, externo e interno). ${ }^{99}$

Após longos debates, sendo apresentado o anteprojeto inicial da subcomissão, 189 emendas foram apresentadas, muitas delas versando sobre a sistemática da atuação e composição do TCU. Assim, tome-se por exemplo, sem se esgotar as discussões que vieram seguidas, as emendas propostas pelo constituinte Arnaldo Martins, que previa que somente por decisão de dois terços dos membros do Congresso Nacional deixaria de prevalecer o parecer prévio sobre as contas do governo emitido pelo TCU (Emenda 5B0008-3 - rejeitada), ou ainda a relativa à substituição da conjunção "ou" por "e", quando se refere aos notórios conhecimentos dos candidatos a Ministro do TCU, sob o argumento de que a função exigiria todos os requisitos (jurídicos, financeiros, econômicos), e não somente um deles (Emenda 5B0010-5 - rejeitada); a proposta do constituinte Virgílio Távora, alterando a nomeação dos Ministros, que seria realizada pelo presidente do próprio TCU, após aprovação do Senado Federal, sendo que 3/5 da composição do Tribunal seriam indicados pelo Conselho Federal da Ordem dos Advogados do Brasil, Conselho Federal de Economia, Conselho Federal de Contabilidade e Conselho Federal de Administração (Emenda 5B0014-8 - rejeitada); a emenda do constituinte Meira Filho que propunha o número de 11 Ministros para compor o Tribunal (Emenda 5B0064-4 - rejeitada); a criação, sugerida pelo constituinte João Natal, da figura do Auditor-Geral, que seria o responsável pela fiscalização financeira e orçamentária, já que o TCU se tornaria parte do Poder Judiciário, fazendo aquele as vezes deste (Emendas 5B0105-5 e 5B0107-1 - rejeitadas); a emenda do constituinte Wilson Campos que permitia a criação de Tribunais de Contas dos Municípios, desde que fosse por lei complementar (Emenda 5B0114-4 - rejeitada); o plano do constituinte Orlando Bezerra

\footnotetext{
98 HELENA, Eber Zoehler Santa. V.b-Subcomissão Orçamentária e Fiscalização Financeira. In: BACKES, Ana Luiza et al (orgs.). Audiências públicas na Assembleia Nacional Constituinte: a sociedade na tribuna. Brasília: Câmara dos Deputados, 2009, p.336-337.

99 HELENA, Eber Zoehler Santa. V.b-Subcomissão Orçamentária e Fiscalização Financeira. In: BACKES, Ana Luiza et al (orgs.). Audiências públicas na Assembleia Nacional Constituinte: a sociedade na tribuna. Brasília: Câmara dos Deputados, 2009, p.326.
} 
determinando que o TCU emitisse parecer prévio sobre as contas dos três poderes, separadamente (Emenda 5B0133-1 - rejeitada). ${ }^{100}$

No entanto, dentre as emendas apresentadas, uma das que obteve sucesso, alterando sensivelmente o teor do anteprojeto, foi a do constituinte Wilson Campos. O projeto inicial do relator, no que versa sobre a composição do TCU, prescrevia que os Ministros seriam nomeados pelo Presidente da República, dentre cidadãos de mais de 35 anos de idade, sendo 2/3, após aprovação do Congresso Nacional, dentre cidadãos com reputação ilibada e notório saber jurídico, econômico, financeiro ou de administração pública, e 1/3 dentre auditores indicados pelo Tribunal, com base nos critérios de merecimento e antiguidade. Contudo, a emenda apresentada por Wilson Campos (Emenda B50114-4), e aprovada com 12 votos favoráveis e nenhum contra, e que se incorporou ao anteprojeto final aprovado pela Subcomissão Temática, finalizada em maio de 1987, mudava os termos de como se dariam as nomeações.

Desta feita, o Poder Executivo não teria qualquer participação na formação do corpo de ministros do TCU, pois, conforme aquele constituinte, "parece-nos de todo recomendável afastar-se, tanto quanto possível, do processo de investidura de seus Ministros, qualquer margem de influência do Poder Executivo". Ademais, buscou-se conciliar a indicação política com o critério de escolha mediante concurso público, atendendo aos anseios das duas posições existentes nos trabalhos da Constituinte.

Já na fase da Comissão do Sistema Tributário, Orçamento e Finanças - da qual fazia parte a Subcomissão acima referida -, sob a relatoria de José Serra, o substitutivo ao anteprojeto apresentado pela Subcomissão Temática de Orçamento e Fiscalização Financeira, pelo menos no que é pertinente à fiscalização do orçamento e aspectos sobre o TCU, sofreu significativas mudanças. Na parte referente à composição do Tribunal, o substitutivo ao anteprojeto ${ }^{101}$ (que permaneceu na redação do anteprojeto consolidado pela Comissão) retirou a escolha de parcela dos membros do TCU que seria realizada por meio de concurso público, bem como aboliu a vitaliciedade de $2 / 3$ dos Ministros (os escolhidos pelo Congresso), sendo esta mantida somente para o integrante indicado pelo Presidente da República. É perceptível aqui a pressão externa do

100 ASSEMBLEIA NACIONAL CONSTITUINTE. Comissão do Sistema Tributário, Orçamento e Finanças. Subcomissão de Orçamento e Fiscalização Financeira. Emendas ao anteprojeto do relator da subcomissão. Volume 152. Brasília: Centro Gráfico do Senado Federal, 1987-1988.

101 "Art. 61 - Os Ministros do Tribunal de Contas da União serão nomeados pelo Presidente do Congresso Nacional, dentre brasileiros de reputação ilibada e notórios conhecimentos jurídicos, econômicos, financeiros ou de administração pública, obedecidas as seguintes condições: I - um terço, indicado pelo Presidente da República, com aprovação do Congresso Nacional; II - dois terços, escolhidos pelo Congresso Nacional, com mandato de seis anos, não renovável, sendo: a) um terço dentre profissionais indicados por entidades representativas da sociedade civil, na forma que a lei estabelecer; e b) um terço dentre Auditores, substitutos legais de Ministros, ou membros do Ministério Público junto ao Tribunal de Contas, por este indicado, em lista tríplice, alternadamente, segundo os critérios de antiguidade e de merecimento" (ASSEMBLEIA NACIONAL CONSTITUINTE. Comissão do Sistema Tributário, Orçamento e Finanças. Substitutivo do Anteprojeto (Nova redação). Volume 146. Brasília: Centro Gráfico do Senado Federal, 1987-1988, p.10). 
Poder Executivo que, ao ver seu poder sendo mitigado, pelo menos no que concerne à fiscalização pelo TCU, na fase da Subcomissão Temática, conseguiu restabelecer a possibilidade de efetuar a nomeação de pelo menos um dos membros, sendo este o único assegurado com a vitaliciedade.

Algumas alterações ainda se realizaram na ocasião dos trabalhos da Comissão de Sistematização, cujo projeto de Constituição aprovado, após o segundo substitutivo do relator, acrescentou um requisito temporal na escolha dos membros do TCU, acrescentando a exigência de idade mínima igual a 35 anos, bem como adicionou a exigência de idoneidade moral ao candidato. Ampliou igualmente o número de Ministros, que passaram para 11. Alterou-se ainda a forma de escolha do membro do Tribunal a ser realizada pelo Presidente da República, passando-se a exigir a aprovação pelo Senado Federal, e não pelo Congresso Nacional. Por fim, modificou-se a escolha a ser realizada pelo Congresso Nacional.

No momento das deliberações plenárias, no $1^{\circ}$ turno das votações da Assembleia Constituinte, novos rearranjos institucionais fizeram com que as feições do TCU voltassem a se alterar. Assim, em 21 de março de 1988 foi posto em votação o texto resultante da fusão das propostas dos constituintes Adhemar de Barros Filho, Valter Pereira, Victor Faccioni, Arnaldo Prieto, Darcy Pozza, Messias Góis, Bonifácio de Andrada, Eraldo Tinoco, Antonio Mariz e Paulo Roberto Cunha, que tratava sobre a composição do TCU. A referida emenda foi aprovada por 326 votos favoráveis, 25 contrários e 6 abstenções, sendo que seu texto final retirava, por uma maioria esmagadora, a vitaliciedade ${ }^{102}$ de todos os Ministros (de todos eles, salvo os que já o seriam na data da promulgação da Constituição), mantendo um mandato de 6 anos, vedada a recondução. ${ }^{103}$

Aquela redação trazida pela emenda suso tratada foi, posteriormente, objeto de novo debate já no $2^{\circ}$ Turno de votação da Assembleia. Em 24 de agosto de 1988, os constituintes Jarbas Passarinho (Destaque n० 1.93), Fernando Gasparian (Destaque nº 1.9), Arnaldo Prieto (Destaque n॰ 810) e João Agripino (Destaque n 608) apresentaram destaques ao projeto que estava sendo votado, pleiteando a supressão do mandato de 6 anos dos Ministros, retornando, assim, a garantia de vitaliciedade. Defendendo a proposta, o constituinte João Agripino esclareceu, antes que se iniciasse a votação dos

\footnotetext{
102 Como era esperado, os membros do TCU se posicionaram de forma contrária a perda da vitaliciedade, a exemplo do fez o então Ministro Jorge Vargas, que em artigo publicado no jornal "O Estado de São Paulo", declarou que "Seria desejável também, que os Constituintes, através de emenda supressiva, restituíssem a vitaliciedade ao TCU, mantida desde a sua criação em 1891, como forma de preservação de sua independência para julgar, como acontece com todos os outros tribunais superiores" (VARGAS, Jorge. O novo papel do TCU. 0 Estado de São Paulo, São Paulo, 07 jul. 1988, p.2).

103 ASSEMBLEIA NACIONAL CONSTITUINTE. Diário da Assembleia Nacional Constituinte. Ata da 229a Sessão (21 de março de 1988). Brasília: Centro Gráfico do Senado Federal, 1987-1988, p.314.
} 
destaques, que a vitaliciedade não seria do funcionário, mas sim do cargo, e que ela seria fundamental para a proteção das funções exercidas pelos Ministros. ${ }^{104}$

Apesar dos esforços despendidos, os destaques, unificados por meio de uma única emenda, foram rejeitados, uma vez que não se alcançou o quorum mínimo exigido, havendo 205 votos a favor, 132 contra e 4 abstenções. Diante deste quadro, alguns constituintes externaram de imediato sua insatisfação, a exemplo do que fez Victor Faccioni, ${ }^{105}$ ao pedir a palavra e declarar que a eliminação da vitaliciedade constituía um erro, não estando os Ministros do TCU tranquilos para atuar com higidez. Acrescentou ainda que o mandato de 6 anos decidido no $1^{\circ}$ Turno somente ocorreu devido à impossibilidade de entendimento entre os parlamentares para assegurar a vitaliciedade ou ainda um mandato maior de 8 anos. ${ }^{106}$ De igual maneira foi o discurso de Jarbas Passarinho, autor da emenda que buscava trazer de volta o vitaliciamento, momento em que declarou ser extremamente prejudicial um mandato tão reduzido para os fiscais do Governo. ${ }^{107}$

Parecia que a vitaliciedade de fato não mais faria parte da estrutura ministerial de contas a partir da nova Constituição que se formava. Mas não foi assim que aconteceu.

Dois dias após aquela votação, em 26 de agosto de 1988, o constituinte Cid Sabóia de Carvalho apresentou a emenda n. 68, que previa, dentre outras alterações, a mesma supressão do mandato de 6 anos dos Ministros do TCU, já votada anteriormente, retornando a sua vitaliciedade. ${ }^{108}$

Como não podia deixar de ser, houve uma série de protestos dos demais constituintes contrários a essa nova votação. José Genuíno, por exemplo, pediu que houvesse uma racionalização da votação do texto, não devendo haver a apreciação dessa emenda uma vez que já fora apreciado o seu conteúdo anteriormente. ${ }^{109} \mathrm{Em}$ resposta,

104 ASSEMBLEIA NACIONAL CONSTITUINTE. Diário da Assembleia Nacional Constituinte. Ata da 323a Sessão (24 de agosto de 1988). Brasília: Centro Gráfico do Senado Federal, 1987-1988, p.167.

105 Cabe salientar que o posicionamento de Victor J. Faccioni remanesceu, depois de anos, harmônico com o discurso proferido na Constituinte. Verifica-se, assim, que em artigo publicado em virtude dos 20 anos da Constituição brasileira de 1988, ele manteve as seguintes assertivas: "A manutenção das prerrogativas aos membros dos Tribunais de Contas foi essencial à preservação da sua dignidade funcional e à eficácia das decisões do colegiado" (FACCIONI, Victor J.. A Constituição de 1988 e os tribunais de contas: 20 anos. Revista gestão pública e controle, Salvador, v.2, n.5, nov. 2009, p.34).

106 ASSEMBLEIA NACIONAL CONSTITUINTE. Diário da Assembleia Nacional Constituinte. Ata da $323^{\text {a Sessão }}$ (24 de agosto de 1988). Brasília: Centro Gráfico do Senado Federal, 1987-1988, p.182.

107 ASSEMBLEIA NACIONAL CONSTITUINTE. Diário da Assembleia Nacional Constituinte. Ata da 323a Sessão (24 de agosto de 1988). Brasília: Centro Gráfico do Senado Federal, 1987-1988, p.184.

108 ASSEMBLEIA NACIONAL CONSTITUINTE. Diário da Assembleia Nacional Constituinte. Ata da 327a Sessão (26 de agosto de 1988). Brasília: Centro Gráfico do Senado Federal, 1987-1988, p.429.

109 ASSEMBLEIA NACIONAL CONSTITUINTE. Diário da Assembleia Nacional Constituinte. Ata da 327a Sessão (26 de agosto de 1988). Brasília: Centro Gráfico do Senado Federal, 1987-1988, p.429. 
o Presidente da Assembleia Constituinte determinou que, em vista de a matéria já ter sido analisada, e não haver coincidência entre as emendas, a votação seria realizada. ${ }^{110}$

O constituinte Roberto Freire também demonstrou sua indignação, declarando que o arbítrio estava valendo mais do que o Regimento interno da Assembleia. ${ }^{111}$ Ademar Andrade igualmente se posicionou afirmando que "depois disto que está sendo feito, neste momento, qualquer coisa vai ser possível fazer-se nesta Casa. Estamos votando duas vezes a mesma matéria, Sr. Presidente".112

Em que pesem os protestos, a votação ocorreu tendo como resultado a aprovação ${ }^{113}$ da emenda, com 291 votos favoráveis, 95 contrários e 1 abstenção, ${ }^{114}$ ou seja, restituiu-se a vitaliciedade dos membros do Tribunal de Contas da União, existente até hoje.

Independente de qualquer opinião acerca da vitaliciedade dos membros do TCU, o que se pode presumir, sem se pretender uma análise aprofundada e completa da série de fatores e jogos políticos dos bastidores, o que não permite uma asserção comprovada, mas, em certa medida, comprovável, é que o TCU possui um poder político muito maior do que se aparece à primeira vista. O embate travado no curso da Constituinte, respeitante ao TCU, girou em torno, desde o princípio, da questão de suprimir poderes e vinculações do Poder Executivo com o Tribunal, e, consequentemente, ampliar a interferência do Parlamento brasileiro naquele órgão de controle externo. Inconscientemente ou não, este cenário concorreu para a retirada de poderes dos próprios membros do TCU, cuja expressão maior é a vitaliciedade. ${ }^{115}$ No entanto, o jogo político não resistiu à força daquela instituição centenária de controle, tornando a

\footnotetext{
110 Como noticiado pelo periódico "Jornal de Brasília" (Manobra devolve a TCU vitaliciedade a ministro. 27 ago. 1988, p.4), em 27/08/1988, "quando o deputado Ulysses Guimarães anunciou o destaque do senador Cid Sabóia, as lideranças do PSDB, PT e PCB questionaram a prejudicialidade do destaque. A resposta de Ulysses foi seca: 'Não está prejudicado, essa é uma matéria diferente'. O líder do PSB, deputado Adhemir Andrade, tentou contrargumentar, mas foi advertido pelo presidente da Constituinte para se'inteirar melhor sobre as matérias em votação"'.

111 ASSEMBLEIA NACIONAL CONSTITUINTE. Diário da Assembleia Nacional Constituinte. Ata da 327a Sessão (26 de agosto de 1988). Brasília: Centro Gráfico do Senado Federal, 1987-1988, p.429.

112 ASSEMBLEIA NACIONAL CONSTITUINTE. Diário da Assembleia Nacional Constituinte. Ata da 327a Sessão (26 de agosto de 1988). Brasília: Centro Gráfico do Senado Federal, 1987-1988, p.430.

113 A imprensa brasileira deu grande destaque ao ocorrido, sendo matéria obrigatória em diversos jornais pelo país. Assim, em 27 de agosto de 1988, alguns dos principais jornais noticiaram: JORNAL DE BRASÍLIA. Manobra devolve a TCU vitaliciedade a ministro. 27 ago. 1988, p.4; O GLOBO. Plenário restabelece vitaliciedade no Tribunal de Contas. 27 ago. 1988, p.5; CORREIO BRAZILIENSE. Ministros do TCU recuperam vitaliciedade. 27 ago. 1988, p.4.

114 ASSEMBLEIA NACIONAL CONSTITUINTE. Diário da Assembleia Nacional Constituinte. Ata da 327a Sessão (26 de agosto de 1988). Brasília: Centro Gráfico do Senado Federal, 1987-1988, p.429.

115 Vale observar que a elevação do número de Ministros do TCU para 11, aprovada na Comissão de Sistematização, diminuiria a noção de exclusividade existente em círculos reduzidos de poder. Ou seja, quanto mais dividido o poder entre várias pessoas, menor parcela daquele cada um possui.
} 
conferir, ao arrepio das normas regimentais da Constituinte, todas as prerrogativas que já possuíam os membros do TCU na ordem constitucional passada.

Conforme destaca Marianna Montebello Willeman, os Ministros do TCU, bem como outros representantes dos Tribunais de Contas subnacionais, foram atores extremamente importantes nessa fase de deliberação da Constituinte, construindo fortes alianças que apoiaram a preservação de aspectos considerados centrais para o desenho daquele órgão de controle. ${ }^{116}$

Acrescente-se, em tom de desfecho, que havia igualmente interesse dos congressistas (parte significativa deles, ao menos) na manutenção de prerrogativas e a forma de indicação dos membros do TCU, justamente pela maneira como sempre ocorreu a nomeação dos Ministros do TCU (visto nos capítulos anteriores). Ou seja, os congressistas tinham interesse direto na manutenção da estrutura do TCU, pois seriam eles os prováveis beneficiados, no futuro, a concorrer às vagas de Ministros, já que a regra sempre foi a manutenção de um perfil político das indicações.

\subsubsection{As alterações da LINDB (Lei 13.655/2018)}

Em um contexto mais atual, no qual se pode observar manifestações do TCU no curso do processo legislativo, pode-se mencionar a alteração à LINDB trazida pela Lei no $13.655 / 2018$.

Cite-se, primeiramente, a comunicação emitida pelo Presidente do TCU, Ministro Raimundo Carreiro, em 04 de abril de 2018, no qual consta a preocupação do Tribunal de que diversas disposições contidas no projeto de lei possuem teor de "cunho fortemente desfavorável aos órgãos de controle, particularmente em relação ao Ministério Público e aos Tribunais de Contas." Referida comunicação foi remetida ao Ministério da Justiça, à Casa Civil e à Advocacia-Geral da União.

Subsidiando a mensagem do Presidente do TCU, consta uma análise preliminar feita pela Consultoria Jurídica do Tribunal, apontando, de maneira ampla, a inconstitucionalidade de vários artigos constantes do Projeto de Lei n 7.448/2017.

Posteriormente, insistindo na inconstitucionalidade do Projeto de lei em tela, a CONJUR do TCU emite um parecer detalhado e completo, constante no processo TCU/ CONJUR TC 012.028/2018-5.

Ato contínuo, em 16 de abril de 2018, os Ministros do TCU, Raimundo Carreiro, José Múcio Monteiro, Walton Alencar Rodrigues e Vital do Rêgo se encontram pessoalmente com o Presidente da República para demonstrar o "descontentamento geral do Tribunal do Contas"117 em relação ao aludido projeto de lei.

\footnotetext{
116 WILLEMAN, Marianna Montebello. Accountability democrática e o desenho institucional dos Tribunais de Contas no Brasil. Belo Horizonte: Fórum, 2017, p.169.

117 Vide POMPEU, Ana. Presidente e ministros do TCU pedem a Temer que vete mudanças na LINDB. CONJUR. 18 abr. 2018. Disponível em: <https://www.conjur.com.br/2018-abr-18/presidente-ministros-tcu-pedem-temer-vete-lindb>. Aceso em: 12 ago. 2019.
} 
Apesar do projeto de lei ter sido substancialmente aprovado e transformado na Lei no $13.655 / 2018$, alguns dos seus artigos ${ }^{118}$ foram de fato vetados pelo Presidente da República.

Com o veto parcial, o TCU, em 02 de maio de 2018, voltou a se manifestar por meio de seu presidente, declarando que "os vetos apostos a diversos dispositivos do PL 7448/2017 demonstram, de um lado, a procedência das preocupações e dos fundamentos apresentados por este Tribunal, pelo Ministério Público Federal e pelas variadas associações que se manifestaram sobre o tema".

Nesse breve apanhado cronológico dos fatos, sem que se faça qualquer análise quanto ao mérito da alteração da LINDB, ${ }^{119}$ o que se nota é a insistente atuação do TCU para tentar impedir a aprovação de um projeto de lei que era contrário a seus interesses. Seja por meio da emissão de notas e pareceres técnicos, ou por meio de reuniões pessoais com o Presidente da República, a Corte de Contas buscou influenciar diretamente o processo legislativo, tendo, sob certo ponto, ainda que não por mérito seu exclusivamente, ${ }^{120}$ sucesso ao conseguir o veto de alguns artigos do Projeto de Lei n० 7.448/2017.

\subsubsection{Conclusões parciais}

Tratando dos últimos aspectos investigados sobre o caráter político ou não do TCU, relacionados à influência política sofrida e exercida pela Corte, as conclusões não podem ser outras a não ser da configuração política do Tribunal.

É evidente que as atividades do Tribunal não se circunscrevem aos casos e competências analisados. No entanto, a partir do momento em que se apura que ao menos em uma de suas atribuições (a de maior destaque e visibilidade, diga-se de passagem), além de dois exemplos emblemáticos de atuação/envolvimento em deliberações legislativas, a Corte sofre e exerce influências políticas, é possível denominar o órgão como

\footnotetext{
118 Foram vetados integralmente o artigo 25 e parcialmente o artigo 28.

119 Sobre o tema, ver: VITORELLI, Edilson. A Lei de Introdução às Normas do Direito Brasileiro e a ampliação dos parâmetros de controle dos atos administrativos: um novo paradigma. A\&C - Revista de Direito Administrativo \& Constitucional, Belo Horizonte, ano 19, n. 78, p. 195-219, out./dez. 2019; MARTINS, Ricardo Marcondes. As alterações da LINDB e a ponderação dos atos administrativos. A\&C - Revista de Direito Administrativo \& Constitucional, Belo Horizonte, ano 20, n. 79, p. 259-284, jan./mar. 2020; DIDIER, Fredie Souza; OLIVEIRA, Rafael Alexandria. Dever judicial de considerar as consequências práticas da decisão: interpretando o art. 20 da Lei de Introdução às Normas do Direito Brasileiro. A\&C - Revista de Direito Administrativo \& Constitucional, Belo Horizonte, ano 19, n. 75, p. 143-160, jan./mar. 2019.

120 Embora a instituição do TCU tenha uma forte força política individualmente considerada, no caso da alteração da LINDB há que se levar em consideração que, ao lado da Corte de Contas, diversas outras associações e instituições também se manifestaram contrárias ao projeto de Lei n 7.448/2017, podendo-se mencionar a Associação Nacional dos Procuradores da República (ANPR), a Associação Nacional dos Magistrados da Justiça do Trabalho (Anamatra), a Associação dos Juízes Federais do Brasil (Ajufe), a Associação Nacional dos Procuradores do Trabalho (ANPT), a Associação Nacional dos Membros do Ministério Público (Conamp), Sindicato Nacional dos Auditores Fiscais do Trabalho (Sinait), além do próprio Ministério Público Federal.
} 
político, ainda que nas demais condutas ${ }^{121}$ talvez não o seja. Um singelo caráter político, sob o enfoque então analisado, é o suficiente para lhe atribuir essa nomenclatura, já que, o oposto, ou seja, de que não seria político, restaria contaminado pelas condutas investigadas.

Robustecendo o argumento, apura-se que ao decidir e se conduzir com base em fatores/motivos/influências políticas, deixando de lado muitas vezes os aspectos técnico-jurídicos, o TCU se enquadra na classificação de órgão político trazida por Jorge Miranda, segundo a qual a dicotomia entre órgãos políticos e não-políticos seria que os primeiros se movem segundo critérios políticos e os segundos segundo critérios jurídicos, administrativos ou técnicos. ${ }^{122}$

Dos dois aspectos políticos ora escrutinados, sem sombra de dúvidas o mais perigoso é o primeiro, ou seja, o fato do Tribunal sofrer influências políticas externas para o desempenho de suas funções. Não que o primeiro aspecto seja desprovido de problematizações. Ocorre que a verificação de uma atuação do TCU com um caráter corporativista semelhante a um lobby é, para o bem ou para o mal, uma conduta reiterada e comum em diversos setor públicos e privados. Não parece ser algo exclusivo do TCU ou ainda que, a primeira vista, traga efeitos deletérios imediatos para a sociedade e para a própria instituição.

Contudo, quando se nota que a atuação do órgão pode ser comprometida por influências externas, deixando aqui o órgão de atuar com base nos critérios trazidos pelo ordenamento jurídico, e passando a agir (ou se omitir) com base em (des)favorecimentos pautados em aspectos políticos, a própria existência e funcionamento do TCU são postos em xeque.

Enquanto órgão de Estado, cujos agentes exercem uma função pública, voltados sempre para a busca, em última instância, do interesse público, a atuação do TCU deveria ser limitada pela normas jurídicas trazidas pela Constituição e legislação infraconstitucional. ${ }^{123}$ Não se mostra razoável, tampouco republicano, arriscando toda

\footnotetext{
121 É possível distinguir a atuação do TCU em ordinária e extraordinária. A segunda se referiria à atuação prevista no artigo 71, inciso I, da CF, enquanto a primeira englobaria todas as demais competências da Corte. Enquanto a atuação ordinária tem se mostrado, em grande parte, dinâmica, afinada com as alterações legislativas, buscando acompanhar às demandas sociais de controle externo, a apreciação anual das contas governamentais, paradoxalmente à sua relevância, mantém-se com caracteres arcaicos e ultrapassados, apresentando poucas e vagarosas evoluções, tornando-se muito mais um palco de questões políticas do que um instrumento efetivo de controle, cujo potencial de ação e efetividade tem sido minimizado pela forma como tem sido conduzida (CABRAL, Flávio Garcia. O Tribunal de Contas da União na Constituição Federal de 1988. São Paulo: Verbatim, 2014, p.282).

122 MIRANDA, Jorge. Sobre órgãos do Estado. Revista de Direito Administrativo - RDA, Rio de Janeiro, v. 206, out./dez. 1996, p.25.

123 Embora a asserção feita, acerca dos limites da função pública, pareça ser uma obviedade, a sua repetição se mostra necessária, uma vez que rotineiramente há notícias de condutas avessas a esses limites por agentes públicos/instituições públicas no Brasil. Assim, a explicação didática feita por Eneida Desiree Salgado mostra-se oportuna: “(...) a lógica do Estado Constitucional e Democrático de Direito enreda uma série de mecanismos institucionais para se fazer funcionar. Um sistema de separação de poderes, de freios e contrapesos, de
} 
a base de um Estado Democrático de Direito, que agentes públicos possam desconsiderar as normas jurídicas as quais são vinculados para a sua atuação e venham a se comportar com base em fatores meta-jurídicos, fruto de influências políticas e corporativistas, por vezes desconexas com o ordenamento jurídico.

\section{CONCLUSÕES}

Após o desenvolvimento argumentativo realizado até aqui, a primeira constatação evidente que cabe indicar é o fato que denominar o TCU como político dependerá sempre do critério a ser utilizado para lhe conferir essa adjetivação. Por vezes pode ser enxergado como político, em outra ocasiões não.

Assim sendo, embora tenha-se apurado que ainda pairam nos estudos sobre a Corte uma imprecisão em relação a se poderia o TCU ser enquadrado ou não como órgão político, constata-se que essa análise deve percorrer, ao menos, três vestes distintas, porém complementares. A primeira delas diz respeito à composição dos membros do TCU. Sob esta vertente, denominar de político o órgão de controle diz respeito ao fato de que seus membros são (devem ser) oriundos de cargos políticos ou não. A segunda é pertinente à compreensão do caráter político como referente à função que exerce a Corte. Na última concepção, político se relaciona a se o TCU é exercente ou recebedor de influência/pressões políticas na sua atuação.

Quanto ao corpo de Ministros do TCU, conclui-se que na esfera do dever-ser não há que se falar em um Tribunal necessariamente político, uma vez que o delineamento constitucional vigente, ainda que confira a escolha dos membros do TCU aos representantes do Legislativo e Executivo, o faz colocando requisitos mínimos. De igual maneira, nada impede, desde que atendidos aqueles requisitos, que o corpo seja formado por ex-ocupantes de cargos políticos. É dizer, a Constituição não impede nem fomenta a indicação política. Já em relação ao âmbito do ser, a história constitucional brasileira demonstra o viés político do TCU. Ainda que não haja essa exigência constitucional, a grande maioria dos Ministros do TCU (cujo modelo acaba sendo seguido pelos Tribunais de Contas dos Estados) ocupavam, anteriormente a sua indicação, cargos políticos, sendo praxe a nomeação pelo Congresso de seus pares para ocupar o cargo de Ministro.

Quanto a este último ponto, apesar de não haver uma proibição no texto constitucional a esse viés político da Corte, essa situação não é desejável, tendo em vista o

\footnotetext{
controles recíprocos é parte essencial de sua engenharia. Cada um dos órgãos de soberania, em um sistema racional, age de acordo com a sua função e, por força do constitucionalismo, nos limites de suas competências constitucionais. Ainda, em face da democracia, a atuação dos agentes públicos não pode escapar das regras construídas democraticamente, por meio da representação política em sua atuação respeitosa à supremacia formal e material da Constituição" (SALGADO, Eneida Desiree. Populismo judicial, moralismo e o desprezo à Constituição: a democracia entre velhos e novos inimigos. Revista Brasileira de Estudos Políticos, Belo Horizonte, n. 117, jul./dez. 2018, p.198).
} 
fato de que serão os Ministros responsáveis por fiscalizar e julgar justamente, dentre outros, ocupantes de cargos políticos, pondo em xeque a imparcialidade objetiva e isenção no momento da tomada de decisões.

No que tange à função desempenhada pelo TCU, verificou-se que não haveria uma função considerada política, em especial nos moldes elaborados pela jurisprudência do Conselho de Estado Francês, uma vez que não há a possibilidade de afastar o controle pelo Poder Judiciário dos atos praticados pela Administração Pública no Brasil (ponto característico da função política ou de governo na construção francesa). Mesmo em outro sentidos que se possa atribuir à função política o Tribunal não a exerce, já que não desempenha gestão superior sobre os atos do Estado, tampouco inova primariamente na ordem jurídica. No mesmo sentido, tendo em vista que o TCU exerce uma função administrativa, ainda que haja a possibilidade de exercer certas competências discricionárias, ele não possui uma discricionariedade ampla (que poderia ser rotulada como política), estando sempre limitado pelas normas jurídicas na sua atuação.

Por derradeiro, no que concerne à influência política sofrida e exercida pela Corte, as conclusões não podem ser outras a não ser da configuração política do Tribunal. Analisando o exercício da competência de emitir parecer acerca das contas de governo, o TCU em diversos momentos não exerceu a contento suas atribuições, sendo influenciado por pressões políticas externas, por envolver o alto escalão da política. De outra banda, relacionado à influência que exerce sobre os processos legislativos, a investigação sobre seu papel nos trabalhos da Constituinte brasileira e nas recentes alterações da LINDB, demonstram que a Corte busca exercer lobby e pressões institucionais sobre os rumos da atividade legislativa.

Logo, pode-se apontar que não há uma estrutura normativa constitucional que aponta o TCU como um órgão político quanto a sua composição, embora acabe sendo na prática; a Corte não é política no que se refere ao exercício da função que exerce; o Tribunal mostra-se político quanto à influência sofrida e exercida.

\section{REFERÊNCIAS}

ALMEIDA, Francisco Carlos Ribeiro de. A verdadeira função do Tribunal de Contas da União no processo orçamentário. Revista TCU, Brasília, v.32, n.87, p.15-26, jan./mar. 2001.

ALMEIDA, Guilherme Henrique de la Rocque. Lei orgânica do Tribunal de Contas da União anotada. Normativos correlatos. Belo Horizonte: Fórum, 2006.

ASSEMBLEIA NACIONAL CONSTITUINTE. Comissão de Sistematização. Substitutivo do Relator (Segundo). Volume 242. Brasília: Centro Gráfico do Senado Federal, 1987-1988. 
ASSEMBLEIA NACIONAL CONSTITUINTE. Comissão do Sistema Tributário, Orçamento e Finanças. Subcomissão de Orçamento e Fiscalização Financeira. Anteprojeto da subcomissão. Volume 155. Brasília: Centro Gráfico do Senado Federal, 1987-1988.

ASSEMBLEIA NACIONAL CONSTITUINTE. Comissão do Sistema Tributário, Orçamento e Finanças. Subcomissão de Orçamento e Fiscalização Financeira. Atas das Reuniões. Brasília: Centro Gráfico do Senado Federal, 1987-1988.

ASSEMBLEIA NACIONAL CONSTITUINTE. Comissão do Sistema Tributário, Orçamento e Finanças. Subcomissão de Orçamento e Fiscalização Financeira. Emendas ao anteprojeto do relator da subcomissão. Volume 152. Brasília: Centro Gráfico do Senado Federal, 1987-1988.

ASSEMBLEIA NACIONAL CONSTITUINTE. Comissão do Sistema Tributário, Orçamento e Finanças. Substitutivo do Anteprojeto (Nova redação). Volume 146. Brasília: Centro Gráfico do Senado Federal, 1987-1988.

ASSEMBLEIA NACIONAL CONSTITUINTE. Diário da Assembleia Nacional Constituinte. Brasília: Centro Gráfico do Senado Federal, 1987-1988.

BACKES, Ana Luiza; AZEVEDO, Débora Bithiah de; ARAÚJO, José Cordeiro de. Introdução. In: BACKES, Ana Luiza et al (orgs.). Audiências públicas na Assembleia Nacional Constituinte: a sociedade na tribuna. Brasília: Câmara dos Deputados, 2009. p.13-19.

BANDEIRA DE MELLO, Celso Antônio. Curso de direito administrativo. 33.ed. São Paulo: Malheiros, 2016.

BRASIL. Supremo Tribunal Federal. Adi no 2.597. Relator: Ministro Eros Roberto Grau. Diário de Justiça. Brasília, 17 ago. 2017.

BRITTO, Carlos Ayres. O regime constitucional dos Tribunais de Contas. Fórum Administrativo FA, Belo Horizonte, a. 5, n. 47, jan. 2005.

CABRAL, Flávio Garcia. $\mathbf{O}$ conteúdo jurídico da eficiência administrativa. Belo Horizonte: Fórum, 2019.

CABRAL, Flávio Garcia. O TCU na Constituinte de 87-88: a estruturação da Corte de Contas. In: VIEIRA, Bruno Soeiro; OLIVEIRA, Frederico Antonio Lima de (Orgs.). Direito Público Contemporâneo: ensaios críticos. Volume II. Rio de Janeiro: Lumen Juris, 2017. p.167-191.

CABRAL, Flávio Garcia. O Tribunal de Contas da União na Constituição Federal de 1988. São Paulo: Verbatim, 2014.

CARVALHO, Fábio Lins de Lessa; RODRIGUES, Ricardo Schneider. O Tribunal de Contas no Brasil e seus congêneres europeus: um estudo comparativo. A\&C - Revista de Direito Administrativo \& Constitucional, Belo Horizonte, ano 18, n. 71, p. 225-248, jan./mar. 2018.

CHAVES, Francisco Eduardo Carrilho. Controle externo da gestão pública: a fiscalização pelo legislativo e pelos tribunais de contas. 2.ed. Niterói: Impetus, 2009. 
CITADINI, Antônio Roque. O controle externo da Administração Pública. São Paulo: Max Limonad, 1995.

COMISSÃO PROVISÓRIA DE ESTUDOS CONSTITUCIONAIS. Anteprojeto Constitucional. Diário Oficial da União, seção 1, 26 set. 1986.

CORREIO BRAZILIENSE. Ministros do TCU recuperam vitaliciedade. 27 ago. 1988, p.4.

COUTINHO, Doris de Miranda; SANTOS, Aline Sueli de Salles. O papel do Tribunal de Contas frente à accountability. A\&C - Revista de Direito Administrativo \& Constitucional, Belo Horizonte, ano 18, n. 72, p. 209-233, abr./jun. 2018.

CRETELLA JR., José. Teoria do ato de governo. Revista Inf. Legisl., Brasília, a.24, n.95, p.73-84, jul./ set. 1987.

DECOMAIN, Pedro Roberto. Tribunais de Contas no Brasil. São Paulo: Dialética, 2006.

DIÁRIO DE PERNAMBUCO. Tcu tem que deixar de ser um órgão político, dia líder de governo. Diário de Pernambuco. 06 out. 2015. Disponível: https://www.diariodepernambuco.com.br/app/ noticia/politica/2015/10/06/interna_politica,602267/tcu-tem-que-deixar-de-ser-um-orgao-politico-diz-lider-do-governo.shtml. Acesso em: 20 ago. 2019.

DI PIETRO, Maria Sylvia Zanella. Direito administrativo. 30.ed. Rio de Janeiro: Forense, 2017.

DIDIER, Fredie Souza; OLIVEIRA, Rafael Alexandria. Dever judicial de considerar as consequências práticas da decisão: interpretando o art. 20 da Lei de Introdução às Normas do Direito Brasileiro. A\&C - Revista de Direito Administrativo \& Constitucional, Belo Horizonte, ano 19, n. 75, p. 143-160, jan./mar. 2019.

DUEZ, Paul. Les actes de gouvernement. Paris: Dalloz, 2006.

ESCOLA, Héctor Jorge. Compendio de Derecho Administrativo. Buenos Aires: Depalma, 1990. V.I.

FACCIONI, Victor J.. A Constituição de 1988 e os tribunais de contas: 20 anos. Revista gestão pública e controle, Salvador, v.2, n.5, p.33-43, nov. 2009.

FAGUNDES, Miguel Seabra. A função política do Supremo Tribunal Federal. Revista de Direito Administrativo - RDA, Rio de Janeiro, v. 134, p.1-10, out./dez.1978.

FERNANDES, Jorge Ulisses Jacoby. Tribunal de Contas do Brasil: jurisdição e competência. 2.ed. Belo Horizonte: Fórum, 2008.

FRAGA, Gabino. Derecho administrativo. 40.ed. México: Porrúa, 2000.

FREIRE, André Luiz. Apontamentos sobre as funções estatais. Revista de Direito Administrativo - RDA, ano 13, n. 248, p. 13-53, mai./ ago. 2008. 
GABARDO, Emerson. O princípio da supremacia do interesse público sobre o interesse privado como fundamento do Direito Administrativo Social. Revista de Investigações Constitucionais, Curitiba, vol. 4, n. 2, p. 95-130, maio/ago. 2017.

GABARDO, Emerson. Os perigos do moralismo político e a necessidade de defesa do direito posto na Constituição da República de 1988. A\&C - Revista de Direito Administrativo \& Constitucional, Belo Horizonte, a. 17, n. 70, p. 65-91, out./dez. 2017.

GARCÍA DE ENTERRÍA, Eduardo; FERNÁNDEZ, Tomás-Ramón. Curso de derecho administrativo. II. 9.ed. Madrid: Thomson Civitas, 2004.

GRACIE, Ellen. Notas sobre a revisão judicial das decisões do Tribunal de Contas da União pelo Supremo Tribunal Federal. Revista TCU, Brasília, a.38, n.110, p.7-14, set./dez. 2007.

GUIMARÃES, Edgar. O controle das licitações pelos Tribunais de Contas. Fórum de Contratação e Gestão Pública - FCGP, Belo Horizonte, ano 5, n. 59, dez. 2006. Disponível em: <http://www. bidforum.com.br/bid/PDI0006.aspx?pdiCntd=38550 >. Acesso em: 10 jul. 2019.

HACHEM, Daniel Wunder. A dupla noção jurídica de interesse público em direito administrativo. A\&C - Revista de Direito Administrativo \& Constitucional, Belo Horizonte, ano 11, n. 44, p. 59110, abr./jun. 2011.

HELENA, Eber Zoehler Santa. V.b-Subcomissão Orçamentária e Fiscalização Financeira. In: BACKES, Ana Luiza et al (orgs.). Audiências públicas na Assembleia Nacional Constituinte: a sociedade na tribuna. Brasília: Câmara dos Deputados, 2009. p.323-340.

JORNAL DE BRASÍLIA. Manobra devolve a TCU vitaliciedade a ministro. 27 ago. 1988, p.4.

JORNAL DE BRASÍLIA. TCU cresce e ministros perdem cargo vitalício. 22 mar. 1988, p.5.

KOSHIMIZU, Ricardo Koiti. Comissão Afonso Arinos elaborou anteprojeto de Constituição. Agência Senado, Brasília, 01 out. 2008. Disponível em: <http://www.senado.gov.br/noticias/comissao-afonso-arinos-elaborou-anteprojeto-de-constituicao.aspx>. Acesso em: 10 jan. 2017.

KELLES, Márcio Ferreira. Controle da administração pública democrática:Tribunal de Contas no controle da Irf. Belo Horizonte: Fórum, 2007.

LEAL, Rogério Gesta. Controle da administração pública no Brasil: anotações críticas. A\&C Revista de Direito Administrativo e Constitucional, Belo Horizonte, ano 5, n. 20, p. 125-143, abr./jun. 2005.

LOUREIRO, Maria Rita; TEIXEIRA, Marco Antônio Carvalho; MORAES, Tiago Cacique. Democratização e reforma do Estado: o desenvolvimento institucional dos tribunais de contas no Brasil recente. RAP - Revista de Administração Pública. Rio de Janeiro, 43(4), p.739-772, jul./ago. 2009.

MACHADO, Audálio José Pontes. Tribunais de Contas Estaduais: indicações, perfil dos conseIheiros e autonomia das instituições. 2017. 82 f. Dissertação (Mestrado) - Curso de Ciência Política, Universidade Federal de Pernambuco, Recife, 2017. 
MARTINS, Ricardo Marcondes. "Políticas públicas" e Judiciário: uma abordagem neoconstitucional. A\&C - Revista de Direito Administrativo \& Constitucional, Belo Horizonte, a. 18, n. 71, p. 145-165, jan./mar. 2018.

MARTINS, Ricardo Marcondes. As alterações da LINDB e a ponderação dos atos administrativos. A\&C - Revista de Direito Administrativo \& Constitucional, Belo Horizonte, ano 20, n. 79, p. 259-284, jan./mar. 2020.

MARTINS, Ricardo Marcondes. Efeitos dos vícios do ato administrativo. São Paulo: Malheiros, 2008.

MARTINS, Ricardo Marcondes. Proporcionalidade e boa administração. Revista da Faculdade de Direito PUC/SP, v.3, n.1, p. 310-338, $1^{\circ}$ sem. 2015.

MARTINS, Ricardo Marcondes. Teoria dos princípios e função jurisdicional. Revista de Investigações Constitucionais, Curitiba, vol. 5, n. 2. p. 135-164, mai./ago. 2018.

MEDAUAR, Odete. Ato de governo. Revista de Direito Administrativo - RDA, Rio de Janeiro, n.191, p. 67-85, jan./mar. 1993.

MEDAUAR, Odete. Controle da administração pública. São Paulo: Editora Revista dos Tribunais, 1993.

MEDAUAR, Odete. Controle da Administração Pública pelo Tribunal de Contas. Rev. Inf. Legisl., Brasília. a.27, n.108, p.121-126, out./dez. 1990.

MODESTO, Paulo. Função Administrativa. Revista do Serviço Público, Brasília, v.46, n.2-3, p.95119, mai./dez. 1995.

MOTTA, Fabrício. Julgamento dos prefeitos municipais: apreciação crítica da mudança imposta pelo Supremo Tribunal Federal. Fórum Municipal \& Gestão das Cidades - FMGC, Belo Horizonte, ano 4, n. 15, p. 38-44, jul./set. 2016.

O ESTADO DE SÃO PAULO. TCU terá 12 Ministros com mandato fixo. 22 mar. 1988, p.7.

O GLOBO. Plenário restabelece vitaliciedade no Tribunal de Contas. 27 ago. 1988, p.5.

O GLOBO. Ministros do TCU terão agora 8 anos de mandato. 22 mar. 1988, p.2.

OLIVEIRA, Júlio Marcelo de. O papel dos órgãos de controle externo no combate à corrupção. Consultor Jurídico. 23 out. 2018. Disponível em: https://www.conjur.com.br/2018-out-23/papeI-orgaos-controle-externo-combate-corrupcao. Acesso em: 25 jun. 2019.

OLIVEIRA, Regis Fernandes de. Ato administrativo. 6.ed. São Paulo: Revista dos Tribunais, 2014. PESSANHA, Charles. Controle externo: a função esquecida pelo Legislativo no Brasil. In:

SCHWARTZMAN, Luisa Farah; SCHWARTZMAN, Isabel Farah; SCHWARTZMAN, Felipe Farah; SCHWARTZMAN, Michel Lent (Orgs.). $\mathbf{O}$ sociólogo e as políticas públicas: ensaio em homenagem a Simon Schwartzman. Rio de Janeiro: FGV, 2009. p.243-258. 
PESSANHA, Charles. O Congresso Externo sob o controle das contas. Insight Inteligência, Rio de Janeiro, n.21, p.122-128, abr./mai./jun. 2002.

PIVETTA, Saulo Lindorfer. Legisladores juízes: Impeachment na Constituição de 1988. 2017. 322 f. Tese (Doutorado) - Curso de Direito, Universidade Federal do Paraná - Ufpr, Curitiba, 2017.

POMPEU, Ana. Presidente e ministros do TCU pedem a Temer que vete mudanças na LINDB. CONJUR. 18 abr. 2018. Disponível em: <https://www.conjur.com.br/2018-abr-18/presidente-ministros-tcu-pedem-temer-vete-lindb>. Aceso em: 12 ago. 2019.

RIBEIRO, Ana Paula. 'TCU é playground de políticos fracassados', diz Joaquim Barbosa. O Globo. 29 ago. 2015. Disponível em: https://oglobo.globo.com/brasil/tcu-playground-de-politicos-fracassados-diz-joaquim-barbosa-17347428. Acesso em: 30 ago. 2019.

SALGADO, Eneida Desiree. Populismo judicial, moralismo e o desprezo à Constituição: a democracia entre velhos e novos inimigos. Revista Brasileira de Estudos Políticos, Belo Horizonte, $\mathrm{n}$. 117, p. 193-217, jul./dez. 2018.

SANTOS NETO, João Antunes dos. Legalidade e decisões políticas. Revista de Direito Administrativo - RDA, Rio de Janeiro, v.234, p.147-175, out./dez. 2003.

SILVA, Artur Adolfo Cotias e. O Tribunal de Contas da União na História do Brasil: evolução histórica, política e administrativa (1890-1998). Prêmio Serzedello Corrêa 1998: Monografias Vencedoras. Brasília:TCU - Instituto Serzedello Corrêa, 1999. p. 19-144.

SIMONETTI, Eliana. Decepção no TCU. Gazeta Mercantil, Brasília, 19 set. 1986, p.23.

SPECK, Bruno Wilhelm. Inovação e rotina no Tribunal de Contas da União: o papel da instituição superior de controle financeiro no sistema político-administrativo do Brasil. São Paulo: Fundação Konrad Adenauer, 2000.

SPECK, Bruno Wilhelm. NAGEL, José. A fiscalização dos recursos públicos pelos tribunais de contas. In: SPECK, Bruno Wilhelm (Org.). Caminhos da transparência: análise dos componentes de um sistema nacional de integridade. Campinas: Editora da Unicamp, 2002. p.227-258.

SUNDFELD, Carlos Ari; CÂMARA, Jacintho Arruda; MONTEIRO, Vera; ROSILHO, André. O valor das decisões do Tribunal de Contas da União sobre irregularidade em contratos. Revista Direito GV, v.13, n.3, p. 866-890, set./dez. 2017.

TRIBUNAL DE CONTAS DA UNIÃO. Relatório e parecer prévio sobre as contas do governo da república. Brasília: TCU, 1991.

TRIBUNAL DE CONTAS DA UNIÃO. Relatório e parecer prévio sobre as contas do governo da república. Brasília:TCU, 1992.

VARGAS, Jorge. O novo papel do TCU. O Estado de São Paulo, São Paulo, 07 jul. 1988, p.2. 
VITORELLI, Edilson. A Lei de Introdução às Normas do Direito Brasileiro e a ampliação dos parâmetros de controle dos atos administrativos: um novo paradigma. A\&C - Revista de Direito Administrativo \& Constitucional, Belo Horizonte, ano 19, n. 78, p. 195-219, out./dez. 2019.

WILLEMAN, Marianna Montebello. Accountability democrática e o desenho institucional dos Tribunais de Contas no Brasil. Belo Horizonte: Fórum, 2017. 